\title{
International Refugee Protection
}

\section{Citation}

David W. Kennedy, International Refugee Protection, 8 Hum. Rts. Q. 1 (1986).

\section{Permanent link}

http://nrs.harvard.edu/urn-3:HUL.InstRepos:16082842

\section{Terms of Use}

This article was downloaded from Harvard University's DASH repository, and is made available under the terms and conditions applicable to Other Posted Material, as set forth at http:// nrs.harvard.edu/urn-3:HUL.InstRepos:dash.current.terms-of-use\#LAA

\section{Share Your Story}

The Harvard community has made this article openly available.

Please share how this access benefits you. Submit a story.

Accessibility 


\title{
International Refugee Protection
}

\author{
David Kennedy
}

\section{INTRODUCTION}

During the summer of 1984, I spent three months in the legal offices of the United Nations High Commissioner for Refugees (U.N.H.C.R.) in Geneva. While there, I spoke with a large number of lawyers, "protection officers" as they are called in the United Nations argot, about their work protecting refugees. I was particularly interested in the notions about international refugee and asylum law which they brought to their work. As I spoke with protection officers and read what they had written about international law, I became fascinated by the relationship between their collective vision of their individual or institutional role as international lawyers and their vision of the international legal or doctrinal fields in which they worked. This article discusses that relationship. I explore changes in the roles of international refugee lawyers at the U.N.H.C.R. and changes in their images of the doctrinal fields of international refugee and asylum law.

Some qualifications are in order before I begin. This is not an article about international asylum and refugee law except as seen by international protection officers. ${ }^{2}$ Nor is it an article about the international institution protecting refugees, except as shaped by images of international legal doctrine. ${ }^{3}$ Still less am I concerned with various national approaches, doctrinal or insti-

1. The views expressed in this article are mine alone, and should in no way be understood to reflect those of any employee of the U.N.H.C.R.

2. Studies of asylum and refugee law which take a broader perspective include: $G$. Goodwin-Gill, The Refugee In International Law (1983); A. Grahl-Madsen, The Status of Refugees in International Law (1967); S. Sinha, Asylum and International Law (1971).

3. For a broader approach to the international institutional work of refugee protection see L. Holborn, Refugees: A Problem of Our Time (1975). 
tutional, to refugees and asylum. ${ }^{4}$ In short, I am concerned only with the play between the professional and doctrinal sensibilities of a rather small group of international lawyers, a great number of whom are civil servants.

Fortunately for an enterprise which addresses the relationship between perceptions and doctrines ${ }_{\text {, }}$ international refugee protection officers form a small, relatively homogenous professional group. Most have worked or continue to work for the U.N.H.C.R., either in Geneva or in the field. They share a strikingly uniform image of the international law with which they work. Despite hearty debate about a number of doctrinal details, such disputes as occur seem safely within a firm professional consensus. This consensus, moreover, has exerted a strong formative impact upon the doctrines with which protection officers work. Even as they imagine their work to be constrained and shaped by the surrounding doctrinal terrain, protection officers have successfully occupied their field. They account for much academic writing in the fields of refugee and asylum law as well as most of the international instruments of refugee protection. As a result, the protection officers's own story has to a certain extent become the story of international refugee and asylum law as well as of the institutions of international refugee protection. I do not, therefore, evaluate their story by reference to other doctrines. Nor do I bring some external perspective to bear upon their institutional role. I engage only in a description and presentation of what I take to be their vision of the institutional and doctrinal framework within which they work. ${ }^{5}$

In some ways, the business of international refugee protection seems to have changed a great deal in the last fifty years. ${ }^{6}$ The U.N.H.C.R. locates its origins in the various international organizations set up in the interwar period which provided assistance to persons fleeing from the Soviet Union and Nazi Germany. The most significant of these organizations were the

4. Of course, the separation of "national" and "international" refugee protection is both artificial and unrealistic. Nevertheless, I approach the matter as those who think of themselves as "international" lawyers do. For summary treatments of national asylum law and policy see R. Plender, International Migration Law (1972); G. Goodwin-Gill, supra note 2.

5. Of course, any such claim to be "inside" or "outside" the institution under study is methodologically troubling. Those purporting to be most rigorously external in their assessment of the U.N.H.C.R. and of international law are among the most eloquent participants in creating the common culture of international refugee protection which I analyze here. For different approaches to the problem of internal critique see M. Foucault, The Archaeology of Knowledge (1972); J. Derrida, Of Grammatology (1974); P. Bourdieu, Outline of A Theory of Practice (1977); J. Culler, On Destruction: Theory and Criticism After Structuralism (1982).

6. For the history of international refugee protection, see generally, L. Holborn, The International Refugee Organization (1956); 1 L. Holborn, supra note 3, at 1-53; M. Proudfoot, European Refugees: 1939-52 (1956); Carlin, "Significant Refugee Crises Since World War Il and the Response of the International Community," 1982 Mich. Y.B. Int'l L. Stud. 3. 
High Commissions created under the auspices of the League of Nations to handle specific refugee flows.

The aftermath of the Second World War also left millions of displaced persons in Europe, particularly in Germany, Austria and Italy. The United Nations Relief and Rehabilitation Administration (U.N.R.R.A.), created primarily to administer refugee camps, undertook the task of repatriating displaced persons to their countries of origin. However, the U.N.R.R.A. found itself ill-prepared to handle the task of resettlement to third countries because many of those displaced from Eastern Europe feared returning home. In 1946, the United Nations established the International Refugee Organization (I.R.O.), a non-permanent body the chief purpose of which was to aid in the large-scale resettlement of refugees. When the original threeyear mandate of the I.R.O. came to an end, the international community was unwilling to continue financial assistance for displaced persons. Yet it was evident that the post-war refugee problem had been far from solved. As people continued to flee Eastern Europe for resettlement in the West, wartorn states that had first welcomed new arrivals now claimed that their economies could handle no more. At the same time, the rising international tensions between East and West changed the flavor of international refugee work. It is in this context that the U.N.H.C.R. was created.

The establishment of the U.N.H.C.R. was a compromise between those who believed that an intergovernmental agency should carry on the work of the I.L.O. and those who sought to shift the burden to front-line European states and voluntary agencies." The "international community," by which was meant "western governments acting collectively," would continue to provide legal "protection" for bona fide refugees, while other displaced persons would need to seek from voluntary agencies and national economies such "assistance" as was still required. When the U.N.H.C.R. was established, the terms "refugee," "protection," and "assistance" took on quite specific meanings.

A "refugee" was no longer simply a displaced person. The Statute of the U.N.H.C.R. and the 1951 Convention on the Status of Refugees defined a "refugee" in specific terms. Instead of grounding "refugee status" in the particular dislocations of post-war Europe, these documents required that for a person to be classified as a "refugee" he or she be, among other things, "outside the country of his [or her] nationality ... owing to a well-founded fear of being persecuted for reasons of race, religion, nationality or political opinion." 8 The class of persons eligible for U.N.H.C.R. protection was defined on an individual basis and with political considerations in mind.

7. 1 L. Holborn, supra note 3, at 38-64 describes the replacement of the I.R.O. by the U.N.H.C.R.

8. Statute of the United Nations High Commissioner for Refugees, 5 U.N. GAOR Annex 1 at 46, U.N. Doc. A/1775 (1950) [hereinafter cited as Statute of the U.N.H.C.R.] 
The U.N.H.C.R. would protect those persons whose eligibility had been certified. In the context of the Cold War, of course, certification of Eastern Europeans in flight to the West was not difficult. The important point, however, is that the U.N.H.C.R. was established in part by creating a classification for it to administer, which set in motion years of legal work attempting to define the U.N.H.C.R.'s "mandate" by applying the Statute's definition of "refugee" to people whose status was ambiguous or uncertain. This particular classification, moreover, in its individual and political approach to "refugees," was more suggestive of those traditionally singled out for "political asylum" by international law than with the larger group of people associated in lay parlance with the word "refugee." This association of "refugee" with "political asylum" has conditioned the responses people have thought to make to the plight of refugees.

Unlike the I.R.O. which had performed a wide variety of services for refugees, from managing temporary housing to issuing passports, the U.N.H.C.R.'s mandate was limited to refugee "protection." 9 While the origins of the term "protection" are obscure, ${ }^{10}$ the term suggests the "protection" normally accorded a national by his sovereign at international law. ${ }^{11}$ As used in the U.N.H.C.R. Statute, the term seems to indicate that, although the U.N.H.C.R.'s work was intended to be "humanitarian," it would not provide "assistance" of a financial or logistical character. Moreover, the U.N.H.C.R.'s work was to be primarily legal, or at least, "non-political." The U.N.H.C.R. would advocate the legal claims of refugees, as a substitute for the sovereign that had been renounced until a replacement for that sovereign could be found. In this manner, "protection" was to be an international legal bridge between periods of national sovereign assimilation. Finally, protection seemed to recall the more limited work of the pre-war international refugee protection agencies which had focused on the problems of those whose "dubious legal status made them a political problem." 12 Therefore, the administration of the definition of refugee became a form of "protection" at least to the extent that a person classified as a "refugee" had a clear legal status at international law.

The early work of the U.N.H.C.R. was primarily legal and technical and involved determining who was a bona fide "refugee" and advocating national resettlement of refugees. Usually, once "certified" or "recognized" as a refugee, a person would receive relatively predictable treatment in his new home. The U.N.H.C.R. "protected" refugees by identifying them, issuing

9. Statute of the U.N.H.C.R., supra note 8.

10. See $1 \mathrm{~L}$. Holborn, supra note 3 , at $99,155$.

11. For useful introductions to national protection materials see H. Steiner and D. Vagts, Transnational Legal Problems 205-247 (1976), and L. Sohn and T. Buergenthal, International Protection of Human Rights 1-136 (1973) (contains a good bibliography on the status of individuals at international law and the protection of nationals abroad).

12. 1 L. Holborn, supra note 3 , at 4 . 
travel documents, assisting in obtaining recognition of their various legal statuses (marriage, property, etc.) and advocating ever more precise guidelines for handling recognized refugees. Lawyers played a key role in this effort, and were central to the work of the U.N.H.C.R.

To those lawyers, protection seemed a matter of international legal definition and advocacy. The U.N.H.C.R. protected refugees by resolving problems of beclouded status and by standing in for "national protection" until a substitute could be found. When asked what responses should be made to the plight of refugees, the U.N.H.C.R. advocated that national governments adhere to the 1951 Convention definition of refugee and to the "recognition" of U.N.H.C.R. certified "refugee status." When protection officers wanted refugees to be accorded some particular treatment, typically they certified them as refugees and tried to persuade national governments to recognize a legal "right" to that treatment which would be accorded pursuant to their certification. The protection officers did not try to provide the treatment nor did they normally engage in political negotiation over its provision.

That U.N.H.C.R. protection officers should have found themselves involved in national "asylum" law and policy therefore is not surprising. "Asylum" had often been seen as a sovereign response to loss of nationality or sovereign protection. The U.N.H.C.R. defined "refugee" in much the same way that both national and international law had usually defined "asylum." Moreover, by associating international protection with national legal solutions rather than with political or financial assistance, the U.N.H.C.R. gave its work a universal and formal flavor which resembled the approach national immigration authorities tended to take in "asylum" situations.

In these ways, the U.N.H.C.R.'s protection officers associated refugee and protection work with national asylum practices, thereby situating its work in a doctrinal field partly of its own devise and significantly cabining its approach to the problems of transboundary displacement. Protection began with certification rather than with flight and sought its origins in aspects of the individual refugee's situation rather than in his native context. Protection ended not at the satisfactory solution of the refugee's difficulties, but at the moment of his successful legal "re-assimilation" to a national legal regime.

In the last two decades, however, international attention has focused on refugee problems different from those which initially preoccupied the U.N.H.C.R. The westward flow of Eastern Europeans has been eclipsed by sudden, large scale transboundary migrations in the Third World - the socalled south-south refugee flows. This shift has drawn into question almost every assumption about international refugee work. Refugees today are less often middle-class people who need legal assimilation in a second European culture than destitute people with a wide variety of special needs. Assistance, rather than protection, has come to comprise by far the greatest por- 
tion of the U.N.H.C.R.'s work. The Office must devise solutions for groups of people rather than for individual refugees. In fact, individual determination of refugee status has become increasingly impractical and beside the point.

In the early days, the cold war politics of the U.N.H.C.R.'s involvement in protection were relatively straightforward. It seemed possible for the U.N.H.C.R. to confine itself to technical legal issues within the context of a larger political consensus on the desirability of resettling Eastern European refugees as expeditiously as possible. In the terms of the Statute, "protection" seemed "humanitarian" and "entirely non-political." The Eastern European states played-and continue to play - no role in the U.N.H.C.R.'s work. South-south refugee flows, however, confront the Office with a thicket of diverse political and ethnic issues, made more complicated by the U.N.H.C.R.'s shift from protection to assistance. Finally, resettlement and legal reassimilation westward seemed the obvious solution to European refugee problems after the Second World War. However, it is no longer clear that resettlement is the appropriate solution for south-south refugee flows - nor is it usually possible. In 1951, the U.N.H.C.R.'s limited approach to protection represented a victory for "overseas" states to which European refugees had sought transport vis-à-vis those states in which displaced persons were located. In the interim, the U.N.H.C.R. has come to regard "overseas" resettlement more favorably, and now "overseas" resettlement seems a more conservative solution than either assimilation in countries of arrival, which is politically difficult or "repatriation," which is politically unpalatable. Overall, the Office has had to confront a much wider range of difficult decisions about what refugees need, what they want, and what solutions it is appropriate for an international agency such as the U.N.H.C.R. to pursue.

In many ways, the U.N.H.C.R.'s response to this changing context has been a model of successful institutional adaption. ${ }^{13}$ Structurally, the Office has developed an "assistance" division parallel to the protection division and has come to rely more heavily upon an Executive Committee composed of concerned states. A changing of the interpretation of the mandate has facilitated a dramatic increase in the scope of the U.N.H.C.R.'s program. Legal determination of refugee status, once an end in itself, now often seems to be merely a bureaucratic prerequisite to assistance. Advocating signature and ratification of the instruments of international refugee law has become a part of a larger propaganda effort. For the protection of refugees, the Office seems to rely far more heavily upon sophisticated political negotiation and

13. For a suggestive study of such international institutional adaption, see Dufty, "Organizational Growth and Goal Structure: The Case of the ILO," 26 International Organization 477 (1972). On the U.N.H.C.R.'s changing role, see 1 L. Holborn, supra note 3; Garvey, "Toward a Reformulation of International Refugee Law," 26 Harv. Int'l L. J. 483 (1985); 1982 Mich. Y.B. Int'l L. Stud. 
the provision of financial or technical assistance in specific cases than upon uniform legal standards. Protection officers now readily acknowledge the political nature of their work and are willing to negotiate a wide range of solutions beyond those expressly mandated by the instruments whose ratification they publicly urge. Moreover, they continually exhort one another to pay more attention to the politics of context, cause and solution. Although unwilling to relinquish the image of coherent and consistent grounding in international legal consensus, protection officers constantly admit that most of their work is and must be context specific and political.

In other ways, however, the protection business at the U.N.H.C.R. has not changed since 1951. Lawyers continue to dominate protection work and to think in the legal terms developed in the post-war era. The work of protection continues to focus on a few specific issues: individual determination of refugee status, if only for the purpose of ascertaining entitlement to U.N.H.C.R. assistance; advocacy of national adherence to international legal instruments concerning refugees; deference to national solutions, including asylum; and a seemingly endless struggle to tie an international status to a national solution in some normative way, preferably as a matter of international legal doctrine. The politics of refugee flows - their causes and cures - remains outside the bounds of normal protection discussion. ${ }^{14}$

Modern protection officers must reconcile this antiquated image of their business with their willingness to engage in a wide variety of political or humanitarian compromises. Such institutional adaption as they have made to contemporary refugee problems has tended to be done beneath the surface of this outmoded professional image. Often they accommodate these increasingly distinct self-images by differentiating various dimensions of their job-suggesting, for example, that while determining refugee status remains a technical legal task, advocating solutions is appropriately a matter of political negotiation. Often protection officers reconcile their distinct roles by differentiating various doctrinal areas within which they work - suggesting, for example, that refugee law remains formal and internationally consistent, while asylum law, in contrast, is a matter of national political discretion. When working within the former, they live up to their legal self-image. When working within the latter, they do what is necessary, given the regrettable immaturity of the international legal system.

Despite, or perhaps because of, these accommodative practices, the U.N.H.C.R.'s adaption process has been facilitated, frustrated and shaped by shared images of the relationship between the conduct of various classic protection tasks and various traditional conceptions of international legal

14. See Hull, "Displaced Persons," 13 Ga. J. Int'l L. 753, 763 (1983); Martin, "Large-Scale Migration of Asylum Seekers," 76 Am. J. Int'l L. 598 (1982). 
doctrine. In this article, I analyze notions of that relationship that have affected the U.N.H.C.R.'s process of institutional change. I conclude that the adaption process has been shaped most critically by a tendency to conduct refugee protection in three distinct discourses, which I term "jurisdiction," "solutions" and "protection per se." By "jurisdiction" discourse, I mean the practice of delimiting the U.N.H.C.R.'s "mandate" by interpreting and applying the Statute's definition of "refugee." By "solutions" or "remedies" discourse, I mean the practice of considering the treatment that should be accorded refugees by deferring to national assimilation practices while urging adherence to international legal classifications. By "merits" discourse or the practice of "protection per se," I mean the very intensive attempts to link international refugee status to national solutions in some normative fashion.

The 1951 compromise which produced the U.N.H.C.R. differentiated and reinforced these three dimensions of international refugee protection. Yet, increasingly, this framework has hindered the U.N.H.C.R.'s adaption process and created a narrow legal image of the institution's potential. The discourse of protection per se has become stagnated. Jurisdictional work seems either subordinate to assistance or strangely out of touch with the causes of refugee flight. Perhaps most significantly, in response to the internationalization of refugee law, which is so important to the U.N.H.C.R.'s identity, solutions discourse has excluded the U.N.H.C.R. from participation in what seem to be national political decisions concerning solutions to refugee problems. Therefore, despite, or perhaps as a consequence of their various accommodative practices, protection officers tend to be cut off from inquiry into the causes of and solutions to refugee flows.

One symptom of these developments has been a rather peculiar approach to the law of asylum. As refugee law became internationalized, protection officers emphasized its relationship to asylum law. In protection parlance, "asylum" came increasingly to refer to the solution appropriate for bona fide refugees. At the same time, protection officers emphasized asylum's national, political, and "discretionary" character. Both of these tendencies generated an oddly limited concept of asylum among protection officers. Although in many countries asylum tends either to be granted to individuals who fit the Statute's definition of a refugee or at least to be directed to a similar political class, it is not a universally appropriate solution to the problems of those now assisted by the U.N.H.C.R. ${ }^{15}$ Moreover, although often granted on a political basis, the practice of granting asylum is usually governed by law and it is quite common for national asylum law to be influ-

15. See G. Goodwin-Gill, supra note 2, and infra notes 88-117. 
enced by international law. ${ }^{16}$ Traditionally, there has been a rather hearty international law of asylum. ${ }^{17}$

Ironically, protection officers have tended to overemphasize both the need to tie national asylum to international refugee status and the difficulty of doing so. Consequently, the international lawyers and scholars involved in refugee protection work have contributed to the gap between international law and national politics with which they seem to be so starkly presented in the context of Third World refugee flows. Responding to this gap while retaining a sense of the uniqueness of the international refugee protection profession has meant engaging in a number of classic if ultimately frustrating legal debates about the link between refugee status and asylum debates, for example, about an international legal "right" to asylum for refugees.

This article argues for a reimagination of the relationship among protection tasks and for a rejuvenation of "asylum" as an international legal concept and of "refugee" as a term with national political bite. I argue that these changes would not threaten the basis for the protection work of the U.N.H.C.R. Rather, they would release protection energy in a multitude of directions appropriate to the diversity of contemporary refugee problems. To the extent that the U.N.H.C.R. has already started moving in these directions, this article analyzes the interrelated processes by which this institutional and doctrinal evolution has occurred in international refugee work.

\section{OVERVIEW OF PROTECTION DISCOURSE}

\section{A. International Legal Framework for Refugee Protection}

International lawyers concerned with refugee protection typically divide international law relating to refugees into two parts: refugee law and asylum

16. See A. Grahl-Madsen, supra note 2. On the general interpretation of international law and domestic law in the human rights field see International Human Rights Law and Practice 105-172 0. Tuttle ed. 1978) (particularly Carliner, "The Implementation of Human Rights Under U.S. Immigration Law" at 133). On the impact of international law on United States asylum law and practice see Note, Constitutional Limits on the Power to Exclude Aliens, 82 Colum. L. Rev. 957, 968-969 (1982); Fernandez v. Wilkinson, 505 F. Supp. 787, 795-800 (D. Kan. 1980); Harisiades v. Shaughnessy, 342 U.S. 580, 585-586 (1951); Note, "The Constitutional Rights of Excluded Aliens: Proposed Limitations on the Indefinite Detention of Cuban Refugees," 70 Geo. L. J. 1303 (1982). Peter Schuck analyzes the traditional insulation of United States immigration law as a separate "political" and international doctrinal field within United States national law in Schuck, "The Transformation of Immigration Law," 84 Colum. L. Rev. 1 (1984).

17. See The Declaration on Territorial Asylum, G.A. Res. 2312, 22 U.N. GAOR Supp. (No. 16) at 81, U.N. Doc. A/6716 (1967); Havana Convention on Asylum (1928); Montevideo Convention on Political Asylum (1933); Carcas Conventions on Diplomatic and Ter- 
law. ${ }^{18}$ Of the two, refugee law seems primarily, although not exclusively, a matter of public international law, and is considered a component of international human rights law or humanitarian law generally. ${ }^{19}$ Initiated with a series of relatively ad hoc interwar procedures, modern refugee law came into its own after the Second World War with the establishment of the U.N.H.C.R., ${ }^{20}$ and the drafting of the Statute of the United Nations High Commission for Refugees ("Statute"), ${ }^{21}$ and the 1951 Convention Relating to the Status of Refugees ("Convention"). ${ }^{22}$ These documents define "refugee," provide for certain rights relating to juridical status, non-expulsion, freedom of movement, employment, travel documents, participation in national welfare, education and rationing programs, and give the U.N.H.C.R. a role in administering and protecting these rights at the international level. Although the term "refugee" has a variety of specific legal meanings in different national legal systems, the term "refugee law" generally refers to the relatively uniform international doctrinal system of definition and protection. ${ }^{23}$

In contrast, those involved in refugee protection have come to consider asylum law to be primarily, though not exclusively, a matter of national law

ritorial Asylum (1954); see infra notes 88-117. Most familiar, of course, is the international customary law of extraterritorial or "diplomatic" asylum, subject of the Asylum, 1950 IC) Reports 266, and Haya de la Torre, 1951 ICJ 71. See Gavin-Nora, "The Columbian-Peruvian Asylum Case and The Doctrine of Human Rights," 37 Va. L. Rev. 927 (1951); Morgenstern, "Extra-territorial Asylum," 1948 Brit. Y.B. Int'l L. 236; Briggs, "The Colombian-Peruvian Asylum Case and Proof of Customary International Law," 45 Am. J. Int'I L. 728 (1951); Van Essen, "Some Reflections on the Judgments of the International Court of Justice in the Asylum and Haya de la Torre Cases," 1 Int'l \& Comp. L. Q. 533 (1952).

18. For example of someone's dividing it this way, see G. Goodwin-Gill, supra note 2; A. Grahl-Madsen, supra note 2.

19. See, e.g., G. Goodwin-Gill, International Law and the Movement of Persons Between States (1978); G. Goodwin-Gill, supra note 2; A. Grahl-Madsen, The Present International Law Relating to Refugees: Past, Present, Future (1982); A. Grahl-Madsen, supra note 2; J. Simpson, The Refugee Problem (1938); J. Vernant, The Refugee in the Post-war World (1953); P. Weis, Nationality and Statelessness in International Law (1983). For further references see 2 L. Holborn, supra note 3, at 1447-48; A. Maislich, IRIRC, International Bibliography of Refugee Literature (1985).

20. G.A. Res. 428, 5 U.N. GAOR Supp. (No. 20) at 46, U.N. Doc. A/1775 (1950).

21. Statute of the U.N.H.C.R., supra note 8 , at para. 1.

22. Convention Relating to the Status of Refugees, adopted 28 July 1951, entered into force 21 April 1954; 189 U.N.T.S. 137 (1951) [hereinafter cited as Convention]; see Weis, "Legal Aspects of the Convention of 25 July 1951 Relating to the Status of Refugees," 30 Brit. Y.B. Int'I L. 478 (1953). The Convention was expanded to cover refugees outside of Europe and those not displaced by the Second World War by the Protocol Relating to the Status of Refugees, opened for signature 31 January 1967, entered into force 4 October 1967; 606 U.N.T.S. 268 (1967) [hereinafter cited as Protocol]; see Weis, “The 1967 Protocol Relating to the Status of Refugees and Some Questions of the Law of Treaties," 42 Brit. Y.B. Int'l L. 39 (1967).

23. Often supplemented by other relevant doctrines of international public law such as those relating to extradition and statelessness, see, e.g., P. Weis, supra note 19. 
and sovereign discretion. ${ }^{24}$ As a result, the international protection of refugees has focused almost exclusively on refugee law rather than asylum. At first, this rather narrow approach to asylum is difficult to understand. There is, after all an elaborate history of asylum doctrine in public international law, and numerous regional conventions and customary practices define its terms for many states, particularly those in Latin America. ${ }^{25}$ Moreover, even within national law, asylum is rarely a matter simply of political discretion. Indeed, asylum figures in the municipal law of numerous countries, often with constitutional importance and meaning. ${ }^{26}$ Still, for all this, public international law continues to define asylum as the "protection which a State grants on its territory" to a "person who comes to seek it." ${ }^{27}$ Attempts to give the concept more substantive meaning at the international level have failed. ${ }^{28}$

Regardless of how asylum is treated doctrinally, it is easy to see that the notion of "asylum" could pose difficult conceptual problems for those working in refugee protection. Asylum seems unlike other aspects of international law upon which those working with the U.N.H.C.R. normally rely. Asylum has not been codified in an international instrument and one must consequently search for it in a variety of locations. In addition to this "common law" feel, international asylum law seems less to bind states than to enable them. If refugee law limits state discretion, asylum seems to enlarge it. If refugee law seems to create individual rights and state responsibilities, asylum law seems more descriptive than normative. Moreover, the concept

24. Basic works considering asylum include: M. Garcia-Mora, International Law and Asylum as a Human Right (1956), G. Goodwin-Gill, supra note 2; A. Grahl-Madsen, Territorial Asylum (1980) [hereinafter cited as Asylum]; A. Grahl-Madsen, supra note 2; L. Green, The Right of Asylum in International Law (1961); Morgenstern, "The Right of Asylum," 26 Brit. Y. B. Int'I L. 327 (1949); S. Sinha, supra note 2; Weis, "The Present State of International Law on Territorial Asylum," 31 Schweizerishes Jahrbuch fur Internationales Recht 71 (1975). For further references, see A Select Bibliography on Territorial Asylum (ST/Geneva/Lib. Ser. B/Ref.9/1977); and International Refugee Law Basic Bibliography (U.N.H.C.R. Refugee Law Documentation Center, International Protection Division).

25. See, e.g., American Convention on Human Rights, signed 22 November 1969, entered into force 18 July 1979; O.A.S.T.S. No. 36, at 1; O.A.S. Doc. OEA/Ser.K/XVI/1.1, doc. 65, rev. 1, corr. 1 (1970); Convention on Territorial Asylum, adopted 28 May 1954, 34 Pan-Am. T. S. 1; see generally G. Goodwin-Gill, supra note 2, at 104-109; Weis, supra note 24.

26. See generally S. Aiboni, Protection of Refugees in Africa 82-110 (1978); G. GoodwinGill, supra note 2, at 165-203; 2 A. Grahl-Madsen, supra note 2, at 109-130; Avery, "Refugee Status Decision Making: The Systems of Ten Countries," 19 Stan. I. Int'I L. 235 (1983).

27. Institute of International Law, Bath Session, 11 September 1950, 1 Annuaire 167 (1950).

28. Indeed, the only postwar law making conference of the United Nations which failed to produce a convention was the 1977 Conference on Territorial Asylum. See A. GrahlMadsen, supra note 24; Weis, "The Draft UN Convention on Territorial Asylum," 54 Brit. Y.B. Int'l L. 151 (1978). 
of asylum, at least internationally, seems descriptive of a condition rather than of an obligation. To people who imagine that states unbound by law are uncontrolled, refugee law represents cooperation among sovereign states confronting a common problem, while asylum seems within the province of sovereign political discretion. If one views the domain of international institutions to be the progressive achievement of international law, asylum seems an anachronistic holdout. Even when legalized, asylum law seems primarily municipal and beyond the cognitive control of international protection officers, especially in contrast to refugee law, with its international definitions of persons concerned and standards of treatment to be accorded.

Although these differences between refugee and asylum law make it understandable that protection officers do not tend to think of asylum as a matter with which they might be appropriately concerned, in fact those concerned with international refugee protection have tended to exclude asylum from the scope of their work, actively reinforcing these differences. This tendency too is understandable. In a sense, asylum seems to be the opposite, the flip side, of refugee law. Where refugee law is helpful to protection officers in establishing an international normative force against governments on behalf of refugees, asylum, it seems, expresses the limits of the U.N.H.C.R.'s work, the state power against which protection officers struggle. As a result, protection officers tend to do one of three things: (1) ignore asylum; (2) treat asylum as if it, like refugee law, were a matter of international normative understanding; or, (3) most commonly, struggle for the progressive transformation of asylum from the realm of national politics to the realm of international law and cooperation by codification and advocacy.

One might view the paradoxical exclusion of "asylum" another way by focusing on the relationship that these international lawyers perceive between asylum and other branches of international law. On the one hand, as a matter of public international law, it seems that asylum is what is "left over" after the law relating to refugees, statelessness, extradition, human rights, and humanitarian issues has been spelled out. ${ }^{29}$ This is true in the sense that asylum is very much bounded by these other fields of law. One begins to think of asylum when states protect people who are not refugees or would otherwise be extraditable. One defines the special features of asylum protection as those above and beyond the standards of refugee, humanitarian and human rights law. On the other hand, it seems that asylum, as a legal matter, adds nothing to these disciplines. Whatever additional people might be protected or whatever additional protection might be given is fully discretionary. In a sense, this proposition is also true. For example, if a state refuses ex-

29. See J. Pictet, The Principles of International Humanitarian Law (1966); The International Dimensions of Human Rights (Vasak ed. 1982) (two volumes covering every dimension of human rights and humanitarian law referring only eight times, in passing, to asylum). 
tradition of someone not covered by the political offenses exception to a bilateral treaty, we might think of it as a violation of international law rather than as an instance of asylum if the refusal to extradite could not be supported by principles drawn from the international law of refugees, human rights, or from humanitarian law.

Although most commentators on the law of asylum have taken a position between the extremes of this paradox, the unsatisfactory nature of such middle positions may augment the protection officer's sense that asylum can be excluded as a matter of natural political discretion. ${ }^{30}$ Yes, they say, asylum law is primarily municipal and discretionary, but, they then add, for one reason or another, asylum has, or is progressively acquiring, an international legal "aspect." These commentators differentiate asylum law from other branches of international law in a variety of ways, relying on its municipal, procedural, or other special qualities. Oddly, however, commentators simultaneously emphasize the similarity of asylum law to other legal areas with respect to other qualities. These strategies of differentiation and relation converge and ultimately reinforce the image of asylum as the deficient runt of the doctrinal litter from an international legal point of view. For self-styled "realists" this seems inevitable; for others it remains a challenge to the international law-making bureaucracy. Notwithstanding these differences, all of these approaches are situated between two extremes of their own devise: a formal international law and a capricious national politics.

No middle position seems any more or less sustainable than any other. Nor does this paradox seem to be the inevitable starting point for doctrinal thinking. It is not true that asylum is the irreducible "other" of refugee law. Nor is it true that it can simply be treated as or transformed into a useful international legal partner to the refugee law standards spelled out in the Statute and the Convention. Nonetheless, all of the asylum materials attempt to define the boundary between "asylum" and "refugee" law strictly in doctrinal terms, without reference to the institutional framework within which these doctrinal categories have been given meaning. As a result, none of these middle positions seems particularly attuned to the work of a protection officer who must operate within the full range of discourse permitted by the paradoxical diversity of the asylum concept.

This article explores the various positions which have been taken with respect to asylum and refugee law in relation to their use in various dimensions of protection work. Because all concerned feel that refugee law is the mainstay of international protection work, this article focuses on refugee law's ostensible counterpart, asylum, to discover the mechanisms by which refugee law has attained its doctrinal and institutional hegemony. My intent is not so much to establish the doctrinally, historically, or pragmatically true

30. See supra notes $119-124$. 
relationship between asylum and refugee law. Rather, I seek to simplify and preserve both asylum and refugee law as eclectic sources of useful ideas and places for productive and more flexible thinking about protection work in general.

\section{B. The Institutional Framework for Refugee Protection}

International lawyers concerned with réfugee protection commonly characterize their activities in two ways. Some activities they associate with law and thus with formality, conceptual clarity, universalism, and international cooperation. When considering something which they feel belongs to this realm - such as the definition of "refugee" found in the Protocol or the principle of "non-refoulement" - they generally seem to feel that their institutional work is its most legitimate. The basic work of protection seems to, or perhaps is supposed to, take place in this realm. Other activities they associate with pragmatism, and thus with informality, focus on results rather than concepts, regionally or nationally specific approaches, and the politics of sovereign autonomy. When protection officers want to move into this realm, they call it "humanitarian" or "reality" or "the field." When they want to distinguish themselves from it, they call it "politics."

Protection officers often extend these characterizations of activities to the doctrines with which they work. Thus, for example, they often use the term "asylum" to indicate pragmatic and nationally specific protection practices despite the fact that asylum law is not exclusively pragmatic or municipal. If refugee law seems too formal to be an acceptable framework to respond to a given refugee flow, and if protection officers want to seem to be operating within the realm of humanitarian assistance, they might claim to be extending their good offices to asylum-seekers as well as to refugees. This in turn reinforces their sense that asylum is a category beyond international law, more flexible and practical. In contrast, if they want to distinguish those they are assisting from the ordinary aliens whom it would be too politically sensitive to protect, they might again claim to be extending a hand to asylum-seekers as well as to refugees. This use of the word asylum is designed to make the protection provided seem more legal, formal and internationally legitimate than it would otherwise.

As a doctrinal matter, both uses of "asylum" are appropriate. Relative to refugee law, asylum is a more flexible and pragmatic affair. Yet just as refugee law itself exists within a particular political and social context, so asylum exists within a particular legal framework. In this sense, from the point of view of protection work, "asylum" is a shifting signifier that provides both a boundary and an articulation between law and politics - the two protection activities that everyone wants to distinguish but no one seems able to 
separate. Yet, if asylum is an open space which all of these divergent tendencies occupy, it is also structured by the play among these ideas.

The relationships between the various doctrinal meanings given asylum and these underlying tendencies can be seen by contrasting the meanings given asylum in the context of different institutional practices which seem differentially legal or international. For simplicity, the diverse aspects of "asylum" can be clarified by considering their relationship to the various inquiries a protection officer makes as he focuses on what I have termed problems of jurisdiction, solutions, and protection per se. ${ }^{31}$

1. Jurisdiction. First, the protection officer seeks both to justify and limit the competence of the U.N.H.C.R. ${ }^{32}$ Just as each protection officer distinguishes his job from that of his colleagues in assistance or administration, he also distinguishes the U.N.H.C.R. from other international and intergovernmental agencies. The protection officer pursues this practice of institutional differentiation by elaborating the mandate of the U.N.H.C.R. and determining who is and is not of concern to him. Normally this work involves either interpreting and applying settled international law doctrines or developing legal justification for the work of the U.N.H.C.R. with nonprotocol refugees. Compared to other aspects of the U.N.H.C.R.'s work, elaborating the mandate seems most intimately a matter of international law. As specific situations are cabined within doctrinal categories, the U.N.H.C.R. is cut off from its political context as it sustains its image as a legal institution. For example, because the institutional mandate is linked to an individual refugee definition, protection officers allow what they think of as attributes of the individual refugee himself to trigger institutional concern. Once conditions of political oppression are transposed into attributes of

31. See generally 1 L. Holborn, Refugees, supra note 3 , at 151-319. The various functions of the Protection Division have been defined many times in U.N.H.C.R. documents. A good introduction to these materials is Aga Khan, "Legal Problems Relating to Refugees and Displaced Persons," 1 Recueil des Cours 287 (1976); Report on the Seminar of International Protection at Montreux (lanuary 1980) HCR/120/5/80 GE.80-1228 (relating protection by the U.N.H.C.R. to other international protections); S. Krenz, Reflections on Asylum, The Refugee Definition and the International Protection Function of U.N.H.C.R. (March 1983) (unpublished manuscript); Report of the Conference of U.N.H.C.R. Representatives (May 1978) HCR/103/17/78/GE.78-9486 (provides a useful sense of the relationship between protection and other U.N.H.C.R. functions).

32. In the U.N.H.C.R. argot, the "mandate" of the High Commissioner is his legal authority, the "competence" of the Office is the range of activities permitted by the mandate, and "jurisdiction" is the discourse which frames and analyzes the scope of both. There is a large number of internal U.N.H.C.R. documents discussing the breadth of the U.N.H.C.R. mandate and the definition of a "refugee." See L. Sohn, Competence of the United Nations High Commissioner for Refugees (1980) (unpublished manuscript); Fragomen, "The Refugee: A Problem of Definition," 3 Case W. Res. J. Int'l L. 45 (1970); Maynard, "The Legal Competence of the United Nations High Commissioner for Refugees," 31 Int'l \& Comp. L. Q. 415 (1982). 
refugees, the mandate discussion appears to be legal, neutral and international, but must remain cut off from any analysis of the causes of refugee flows.

This first set of protection concerns is wedded to refugee law. Asylum, however, seems to get in the way. Asylum when characterized as a matter of sovereign discretion cannot be granted by the U.N.H.C.R. Therefore, it seems that jurisdiction cannot extend to "asylum" situations unless there are other legal bases for it or until some international legal content can be developed for asylum. As long as jurisdiction is perceived as legal and asylum as political, the U.N.H.C.R.'s jurisdiction will be defined by asylum in a negative way: a protection officer protects until he encounters an asylum situation; that is, so long as he remains within the bounds of refugee law.

The exclusion of asylum from U.N.H.C.R. jurisdiction sustains the U.N.H.C.R.'s institutional image. Even the few exceptions to this exclusion, by their exceptional legal quality, further this image. Yet the exclusion of asylum is the product of an historically specific discourse, resulting more from the development of an international law of refugees and the institutional competencies associated with that development than from anything historically or doctrinally inherent in the institution of asylum. Moreover, as images of an exclusively international and legal refugee problem have faded, the exclusion of asylum has also faded until its greatest buttress is the independence of jurisdiction discourse itself. The Commissioner's competence no longer flows from doctrinal difference. Indeed, the reverse seems true.

2. Solutions. A second and quite different problem that the Protection Division addresses concerns the appropriate solution to a given refugee problem. ${ }^{33}$ Inventing solutions often seems beyond the portfolio of the Protection Division, if only because this work does not seem legal. Rather, solutions work seems to concern assistance - through support, resettlement, repatriation, etc. - of those who have been deemed "refugees" and to raise more political issues. On the one hand, protection officers seem only to consider questions of solution when they can be transformed into legal questions. Thus, for example, the Protection Division thinks about the minimum standards of treatment which "count" as a legally "durable solution." On the other hand, the protection officer seems more easily able to think flexibly about solutions than about the mandate. It seems easier for a protection of-

33. Discourse about solutions is much less directly a part of internal Protection Division memoranda. For discussions of asylum and the perquisites of refugee status, see Notes Presented to the Sub-Committee of the Whole on International Protection by U.N.H.C.R. (collected 1977-1980 in HCR/PRO/3/June 1981); 2 A. Grahl-Madsen, supra note 3, at 134ff; G. Goodwin-Gill, supra note 2, at 47-68. For exceptions to the general lack of direct solutions in related discussions see G. Coles, The Relationship of Protection to Solution in the Refugee Situation (undated) (unpublished manuscript); and D. Luca, La Notion de "Solution" au Probleme des Refugies (1984) (unpublished manuscript). 
ficer, when asked what he seeks, to say "all I can get" than when asked whom he protects, to say "anyone I can find."

As might be expected, asylum plays a quite different role in solution work. Indeed, the protection officer is better able to accept divergent regional or national results than disparate jurisdictional treatment. Asylum is the international legal point of access to solution and not merely the opposite of refugee status. In considering solutions, protection officers raise questions about the specific national statuses which are labeled "asylum." They discuss whether asylum implies a certain standard of treatment and seek to differentiate asylum law from human rights and humanitarian law. Where any separation of asylum from human rights or humanitarian law seems to threaten efforts to clarify jurisdiction, precisely such a separation is helpful in generating approaches to solution. Similarly, where jurisdiction discourse seeks to split asylum from refugee law, solutions rhetoric blurs the boundary between them. In this sense, asylum provides both a boundary and an articulation between the legality of jurisdiction and the politics of solution. The distinctive approaches to asylum characteristic of mandate and solutions discourses contribute to the differences perceived between these two protection activities just as these perceived differences contribute to asylum's contradictory dimensions.

3. Protection per se. Between the issues of jurisdiction and solution stands the third and primary type of protection work: the strategic pursuit of legal and political "protection" for refugees. ${ }^{34}$ Here, the protection officer asks whether he can achieve more in a given situation legally, by invoking legal principles, or politically, through pragmatic negotiation. Although it seems strange that discussions about the methods and instruments of protection should be conducted separately from issues of jurisdiction or of solution, this seems to be the case.

Indeed, it would be possible to collapse issues of protection into questions about the scope of the mandate by focusing on the flexible interpretation of the mandate, acknowledging that it is not strictly legal. Similarly, if we thought of solutions not simply as the happy results of attempts to negotiate for "all you can get" but also as matters of precedent and minimum standards, it would be possible to discuss protection of refugees entirely within solutions discourse. Nevertheless, protection officers customarily discuss "protection" as if it were different from both jurisdictional questions and questions of assistance. As a result (or perhaps a cause), protection seems

34. Direct discussion of protection by protection officers is even rarer than that of solutions. For classic examples, see G. Goodwin-Gill, supra note 2; A. Grahl-Madsen, Asylum, supra note 24 and infra notes 118-132. Those who comment on the work of protection officers from a scholarly perspective, however, have devoted most of their energy to a series of doctrinal debates which seem to fit here. See supra notes 118-132. 
both more pragmatic than issues of jurisdiction and more legal than questions of solution. As a result, "protection per se," being both a legal function and an administrative activity, is an open space between jurisdiction and solution.

In this middle ground between jurisdiction and solutions, asylum raises different problems. On the one hand, asylum stands for politics and situational pragmatism in the debate over protection tactics. Thus, protection officers often take divergent positions about participation in national asylum granting procedures rather than insisting uniformly upon application of the protocol definition. On the other hand, asylum discussions exhibit the desire to legalize and tame politics, perhaps by establishing a right to asylum or by demonstrating that, as an historical matter, "asylum" expresses not merely unqualified sovereign authority, but also an element of mutual respect and cooperation. It is here, in the heart of protection work - in the space between jurisdiction and solutions - that the debate about asylum is most significant.

The debates about asylum which occupy protection officers here have a great deal in common. Each debate begins with the disjuncture established by mandate discourse between international legal protection and the ostensibly national discretionary protection of asylum. Then, in an attempt to overcome the disjuncture, the debate turns to solutions discourse. Thus each debate first stresses the distinctiveness of asylum from refugee status and then seeks to link the two together. This is equally true of debates about the right to asylum, about nonrefoulement and about temporary refuge. ${ }^{35}$

Thus, the three discourses typically engaged in by protection officers (jurisdiction, solutions, and protection per se) are pursued separately and differently. These three discourses vary as to their international nature and their association with sovereign cooperation, or institutional legitimacy. Although each discourse is given a legal patina, they might be arranged on a continuum from jurisdiction, which seems predominantly legal, to solutions, which seems predominantly non-legal. Although most energy seems expended in the debate about protection per se these debates respond in important ways to the issues raised in the more divergent spheres of jurisdiction and solution.

This is particularly apparent in the deployment of the asylum doctrine in these three areas. As asylum is often defined in relation to the concept of

35. In debates having such a structure, it appears that the disjuncture between jurisdiction and solutions can itself be overcome. Paradoxically, by focusing upon issues such as the right to asylum, instead of upon the causes or solutions of refugee flows, the protection officer is able to seem to deal with and connect issues of international and national protection in a way which neither jurisdiction nor solutions discourse permitted. This remains true as long as the disjuncture between debates are structured around its mediation. The interesting aspect of these classic debates is the variety of the ways in which they mediate the disjuncture of jurisdiction and solutions discourse. See supra section V. 
refugee and to other fields of international law exactly as law and pragmatism are themselves opposed, it is not surprising that asylum takes on different aspects and raises different issues in discourses which are more or less legal in their self-conception. The disjuncture between issues of jurisdiction and solution is mediated by protection discourse. Similarly it is the task of protection discourse to mediate the disjunctures that distinguish asylum from other international legal concepts. As a result, the distinctiveness of asylum, like the distinctiveness of jurisdiction, protection and solutions, is a distinctiveness that is constantly and consciously both created and subverted.

Asylum doctrine, like protection per se, is a place in which battles between political and legal or international and municipal visions of refugee protection can be fought. It is not surprising that asylum is a doctrine within which institutional and political struggle can find expression. Emphasizing "asylum" in some contexts means changing the relative legal or universal approach which will be taken. On the one hand, the distinctiveness of asylum helps preserve a sense that there exists a sphere for non-legal activity, thus reinforcing the sense that legal and non-legal activity are different. On the other hand, the exclusion of asylum from refugee law sustains the unity of the U.N.H.C.R.'s protection discourse and its identity as an international legal, non-political institution. Oddly enough, however, the interaction between asylum doctrine and the practice of protection has encouraged people to think of asylum either as the subject for an international cooperative effort or, in the alternative, as the exclusive preserve of national autonomy. These two concepts of asylum create conflicts about its meaning, distort its history, and lead ultimately to preoccupation with a set of classic debates removed from issues of protection or solution.

Neither asylum doctrine nor protection practice can resolve this issue. It can only be expressed and clarified. Protection discourse might be rejuvenated if asylum law were perceived to be available in the struggle between sovereign authority and sovereign cooperation. Such a perception will require recognition of asylum's fluidity as a concept as well as its relationship to other concepts of international law and of U.N.H.C.R. discourse.

\section{INSTITUTIONAL JURISDICTION}

\section{A. Asylum Law, Refugee Law and the U.N.H.C.R. Mandate}

The relationship between doctrines about refugee protection and the role of international institutions in protection is most apparent in attempts to define institutional jurisdiction to protect refugees. To interpret and apply the international definition of "refugee" in the 1951 Convention, the 1967 Protocol or the U.N.H.C.R. Statute is, of course, less to ascertain something essential 
about the individuals, concerns than to elaborate an independent and limited identity for the U.N.H.C.R.

With certain differences in wording, the Convention and Protocol definition of "refugee" corresponds to the Statute enumeration of persons to whom the competence of the High Commissioner shall extend. ${ }^{36}$ Indeed, the Convention provides that it "shall not apply to persons who are at present receiving from organs or agencies of the United Nations other than the U.N.H.C.R. protection or assistance." 37 Protection officers often go to the trouble of certifying someone a "refugee" in order to determine the point at which international institutional responsibility for the individual begins and ends. ${ }^{38}$ The limits of the refugee category elaborated by protection officers reflect the U.N.H.C.R.'s conception of its own mandate and competence, both as an international agency and as the institution within the United Nations system specifiçally charged with protection and assistance of "refugees."

Thought of this way, it is not surprising that the U.N.H.C.R. has attempted to give an internationally recognized meaning to the concept of "refugee." Nor is it surprising that this definition has become less clear as the U.N.H.C.R.'s mandate has changed and expanded. ${ }^{39}$ New bases of jurisdiction, "good offices" for example, have been added to cover alternative categories of people such as "displaced persons," and the concept of refugee has been employed more broadly to permit new forms of assistance and protection. But such movements are exceptions and discussion of the U.N.H.C.R. mandate and the term "refugee" has been dominated by an effort to retain a recognized and distinct international legal category.

This search for distinctiveness has made protection division work in the area of jurisdiction seem particularly formal and legal. Indeed, the U.N.H.C.R. is rightly proud of the contribution to international law that its search for principles, labels and precedents has made. ${ }^{40}$ As a result of the

36. Compare Convention, supra note 22, art. 1, and Protocol, supra note 22, at art. 1 and the Statute of the U.N.H.C.R., supra note 8, at arts. 6-7. Other international definitions of "refugee" are collected in Collection of International Instruments Concerning Refugees (UNHCR, 1979, HCR/IP/1/ENG at 45ff).

37. Statute of the U.N.H.C.R., supra note 8 , at art. 1 (d).

38. This relationship is also expressed by the organizational structure of most scholarly works on the subject which typically consider U.N.H.C.R. competence and refugee status collaterally. See, e.g., A. Grahl-Madsen, supra note 2; G. Goodwin-Gill, supra note 2. Compare S. Krenz, supra note 31 with L. Sohn, supra note 32.

39. See 1 A. Grahl-Madsen, supra note 2, at $142 \mathrm{ff}$; and L. Sohn, supra note 32.

40. Beyond determining its own jurisdiction, U.N.H.C.R., following numerous invitations from the General Assembly, contributes to the "progressive development" of "refugee law." Statute of the U.N.H.C.R., supra note 8, at art. 8(a). See, e.g., Collected Proceedings, Symposium on the Promotion, Dissemination and Teaching of Fundamental Human Rights of Refugees (Tokyo, 1981, GE.82-01591). A most dramatic effort in this direction was U.N.H.C.R. involvement in the 1977 Conference on Territorial Asylum. See A. Grahl-Madsen, Asylum, supra note 24, at 44-68. 
U.N.H.C.R.'s work, "refugee" has become an internationally recognized legal category. Some have suggested that even when national or other authorities apply refugee definitions and standards, their activities should be seen as merely "procedural" determinations, "declaratory in nature," applying what are "essentially international criteria." 41 This legal development in turn enhances the U.N.H.C.R.'s role. The U.N.H.C.R. now feels able to participate in or monitor national refugee certification procedures, advocating consistent outcomes, as part of its supervisory competence with respect to refugee law. As a result, jurisdictional inquiry differentiates U.N.H.C.R. activity and places it upon a firm international legal footing.

This process of differentiation will be successful only if one can distinguish refugee law and the status of "refugee" from something else. Often, that something else is "asylum." In this usage, asylum stands for everything refugee is not: a national, political, discretionary doctrinal category and an institutional practice grounded in sovereign autonomy. For example, while a refugee is entitled to international assistance and protection, an asylee is deprived of it, because, like a national, an asylee has reacquired national protection and assistance. All of the arguments which sustain the U.N.H.C.R.'s centrality to refugee law exclude the Protection Division from asylum which seems anything but legal or international or cooperative. To the extent that the U.N.H.C.R. seems particularly situated to classify people as refugees, it cannot grant asylum and seems to have no authority to conduct or even participate in asylum classification proceedings. States, like the U.N.H.C.R., are given a place in the doctrinal framework for expressions of their autonomy.

So long as asylum and refugee are distinguished in this way, extending the U.N.H.C.R.'s competence to asylum would undermine efforts to mark out a distinct identity for the Protection Division. Either the international legal and humanitarian identity of the U.N.H.C.R. would seem compromised or another category of national political discretion would have to be invented against which to contrast the U.N.H.C.R. In this sense, the otherness of asylum is important to the jurisdictional work of the protection officer. Unfortunately, however, the effort to differentiate asylum and refugee law is not so simple. As a conceptual matter, the disjunction between refugee and asylum doctrine is not as easy to make as it is to imagine the difference between U.N.H.C.R. and other agencies or governments. Even in U.N.H.C.R. work asylum and refugee are never contrasted so sharply. Each is associated in different contexts with both law and politics, international and national competence, sovereign cooperation and sovereign autonomy. Although protection officers seeking to establish various images of the U.N.H.C.R.'s special competence continue to emphasize the dif-

41. G. Goodwin-Gill, supra note 2, at 205. 
ferences between asylum and refugee law, the distinction continues to blur in practice. ${ }^{42}$

\section{B. Historical Precedents}

The disjunction between refugee and asylum that sustains the U.N.H.C.R.'s special competence is particularly apparent when contrasted with the ways in which the two concepts were related prior to 1700 and during the late nineteenth century period of high positivism. ${ }^{43}$ European scholars, who

42. Compare, e.g., Ito, "Social Aspects of the Refugee Phenomenon Today"; Kofner, "Refugee Phenomena Today"; McNamara, "Determination of the Status of Refugees-Evolution of the Definition"; and Hingorani, "International Institutions and the Protection of Refugees," all collected in Proceedings, Symposium of the Dissemination and Teaching of Fundamental Human Rights of Refugees (1982) GE 82-01591. The striking consequence of this subject matter specialization is its progressive disconnection from any social and political context. The questions of causes, transformed into an inquiry about whether someone is a refugee, loses its sociopolitical perspective. This process of depoliticization is continued when one focuses upon the mandate of the U.N.H.C.R., a legal category constituted by legal categories.

43. There have been very few general histories of international legal scholarship. A short standard history is A. Nussbaum, A Concise History of the Law of Nations (1954). Recent general histories include: W. Schiffer, The Legal Community of Mankind (1956) (a skeptical naturalist analysis of the history of scholarship as prologue to the League of Nations and United Nations); I. Brownlie, International Law and the Use of Force by States (1963) (contains a short history of the relationship between law and international political development without internal analysis of legal scholarship); Ehrlich, "The Development of International Law as a Science," 105 Recueil des Cours $177(1962,1)$ (a linear and somewhat superficial treatment of classic international legal scholarship); Gross, "The Peace of Westphalia," $42 \mathrm{Am}$. J. Int'I L. 20 (1948) (a positivist account of the continuing influence of the conceptual system set in place in 1948 on post-World War II international law; contains particularly useful analysis of the scholarship of the late sixteenth and early seventeenth centuries); Onuf, "International Legal Order as an Idea" $73 \mathrm{Am}$. J. Int') L. 244 (1979) (contains interesting and useful analysis of post-1800 scholarship, including such moderns as Hans Kelsen and Richard Falk).

Classic treatments of the field were: D. Von Ompteda, Literatur des gesammten sowohl naturlichen wie positiven Volkerrechts (1785) (a somewhat annotated bibliography); $\mathrm{H}$. Wheaton, History of the Law of Nations in Europe and America Since the Peace of Westphalia (1846) (description of diplomatic practices in the style of the 19th century positivist mode of discourse); K. Von Kaltenborn, Kritik des Volkerrechts (1847) (useful positivist treatment of international legal scholarship since Gentili); E. Nyus, Le Droit International (1912). Perhaps because international law has had a positivist flavor for over a century, histories of the field have concentrated on doctrinal developments. A standard doctrinal history is J. Verzijl, International Law in Historical Perspective (1968). Perhaps because of the disputed boundary between international law and international politics which has been the subject of much modern scholarship, international legal scholarship is seldom treated historically except as an appendage to a history of political theory. See, e.g., R. Ward, An Inquiry into the Foundation and History of the Law of Nations in Europe from the Time of the Greeks and Romans to the Age of Cortius (1795) (perhaps the earliest example of this political approach to international legal history); E. Midgley, The Natural Law Tradition and the Theory of International Relations (1975); A. de la Pradelle, Maitre et Doctrine du Droit des Cens (1950); F. Parkinson, The Philosophy of International Relations (1977); F. Strawell, The Growth of International 
wrote in the early era, did not distinguish international from municipal law, natural from positive law or the law which binds sovereigns from that which binds citizens. ${ }^{44}$ Unlike those who wrote subsequently about issues of world order, these early scholars did not place a public sovereign at the center of their system. ${ }^{45}$ As a result, they did not draw sharp contrasts between sovereigns and citizens and certainly did not assimilate one to the other. Individuals were thought to exist within a relatively unified legal structure, bound by law wherever they found themselves geographically or bureaucratically. While away from home one remained a human being, subject to universal legal provisions and owing allegiance to the sovereign in whose territory one found oneself. The idea of losing protection or of having to apply for a new protector did not arise. Allegiance, in the sense of obedience, was owed to

Thought (1929); I. Brownlie, supra note 43; A. Wegner, Geschichte des Volkerrechts (1963) (a history of legal scholarship which becomes the history of international relations and diplomacy, this volume classifies scholars by their place in political history rather than internal critique); Le Fur, "La Theorie du Droit Natural Depuis le XVII Siecle et la Doctrine Moderne," 18 Recueil des Cours 263 (1927, III) (containing a valuable historical analysis of primitive scholars).

Histories of asylum and refugee law in these periods are fewer. See, e.g., Weis, "Territorial Asylum," 6 Indian J. Int' L. 173 (1966); R. Plender, supra note 4, at 38-70; 1 A. Grahl-Madsen, supra note 2, at 9-12, 49; 2 A. Grahl-Madsen, supra note 2, at 12-20; Reale, "Le Droit d'Asile" 1 Recueil des Cours, 499-554 (1938, 1); G. Goodwin-Gill, supra note 2 , at $1-5$.

44. Typical of this period are the works of F. Vitoria, F. Suarez, and H. Grotius. Vitoria's major works are: Reflections Theologicae (1557); "De Indis Recenter Inventis" and "De Jure Belli Hispanorum in Barbados," in Classics of International Law (1917) (the last two relate to international law).

Suarez's most comprehensive treatise is On Laws and God the Lawgiver (1612) (De legibus ac Deo Legislatore). Of his theological works, two contain discussions of issues which we would recognize as part of international law. The treatises $A$ Work on the Three Theological Virtues: Faith, Hope, and Charity (1621) (De Triplici Virtute Theologica, Fide, Spe, et Charitate) considers treatment of unbelievers, including foreign heathens, in the book On Faith, and the law of war in the book On Charity. His shorter work, A Defense of the Catholic and Apostolic Faith (1621) (Defensio Fidei Catholicae et Apostolicae Adversus Anglicanae Sectae Errores) is a theological refutation of the Anglican faith which considers the supremacy of papal power and the possibility that a temporal sovereign might be deposed by the Pope should he overstep his authority. Aspects of these three works bearing on international law are translated and collected in Classics of International Law: Selections from Three Works of Francisco Suarez U.B. Scott ed. 1917).

Grotius' major work: On the Law of War and Peace (1625) (De Jure Belli ac Pacis, Libri Tres) in The Classics of International Law (J.B. Scott ed. 1925). On international legal scholarship of this period see Kennedy, "Primitive Legal Scholarship," Harv. Int'l L. J. (forthcoming 1985).

45. This point is made by many historians considering these texts. See, e.g., A. Nussbaum, supra note 43, at 71-79; G. Mattingly, Renaissance Diplomacy (1955). The presumption of a holistic moral order which is indicated by this methodology had been confused with later more traditional approaches which elaborated norms deductively from a selfconscious theoretical structure. The point of primitive holism is that it is not a selfconscious vision of this sort with methodological rules of deduction and internal criticism. See, e.g., J. G. Scott, The Spanish Origin of International Law (1932) (crediting Vitoria with a notion of "the international community"). 
sovereigns, and although problems of conflicting allegiances to home and host sovereign arose, the sharp boundaries of legal jurisdiction and sovereign protection had not yet been developed. Texts of this early period did not distinguish the refugee from the asylee, or refugee status from asylum. ${ }^{46}$

Scholarship of the era of high positivism took a completely different approach. ${ }^{47}$ The sovereign was the center of the legal structure. In addition, municipal and international as well as positive and natural law were sharply distinguished. In the era of high positivism, nothing could be more different than the respective situations of citizens and sovereigns. Individuals, for purposes of international law, were more or less fully assimilated to sovereigns who, it was thought, gave them "nationality" and "protection." 48 The notion of protection, while nominally international, actually referred to the entirely municipal nature of individual legal recourse. As a result, nationality was by and large a municipal, legal status, and individuals were thought to be situated in one or another polity. ${ }^{49}$

Within high positivism's conception of sharply accentuated national boundaries and sovereign competencies, it is easy to understand the origins of modern concepts of asylum and refugee. If one's basic status was determined by assimilation to a particular state, travelers and others who became detached from one place would need to be reattached elsewhere in order for the image of assimilation to be sustainable. ${ }^{50}$ During this era, asylum began to be seen as a consistent term of art connoting a form of protection resulting from national boundaries. ${ }^{51}$ Asylum was less a status to be granted to particular individuals than a condition resulting from the limits of territorial jurisdiction. In this way, asylum became an international term of art in response to the development of a unified structure of jurisdiction doctrine.

In addition, as nationality doctrine split off from criminal jurisdiction and extradition, the developing concept of asylum was split from naturalization. With the development of systematic extradition practices, asylum came to be seen at least partly as a nationally granted status. Unlike naturalization, which was viewed as a status granted as a discretionary response to statelessness, asylum was not a status which needed to be granted. Nor was asylum

46. See Weis, supra note 43 , at $174-175$.

47. Typical of this early period were the texts of Pufendorf, De Jure Naturae et Gentium (1934), and C. Wolff, Jus Gentium, (1934); Vattel, Le droit des Gens (1758). Classic texts of high positivism include the treatises of $H$. Wheaton, supra note 43; see generally A. Nussbaum, supra note 43; R. Plender, supra note 4, at 50ff; Reale, supra note 3, at $543 \mathrm{ff}$.

48. See R. Plender, supra note 4; Reale, supra note 43; 1 A. Grahl-Madsen, supra note 2, at 7, 9-11, 53 \& 78-84.

49. See 1 A. Grahl-Madsen, supra note 2, at 78-84; R. Plender, supra note 4, at 45-55.

50. It is only in this period that "statelessness" is regarded as a difficulty. See $1 \mathrm{~A}$. GrahlMadsen, supra note 2, at $76 \mathrm{ff}$.

51. See 2 A. Grahl-Madsen, supra note 2, at 3-22. 
linked to any international notion such as "statelessness," much less "refugee."

In this high positivist vision, asylum was the important term, and refugee was merely one possible description of its factual antecedent. People were not thought of as "refugees" needing asylum but as asylees who perhaps had been refugees. In contrast, those in need of citizenship were "stateless." In Latin America, the word "asylee" referred both to the asylum seeker and the asylum beneficiary, taking refugee out of the equation altogether. ${ }^{52}$

Prior to the effort to internationalize refugee status there was no uniform notion of a refugee as a person in limbo. Nor was there any well-established notion of an internationally recognized extralegal sovereign discretion to grant asylum. People enjoyed asylum for a variety of reasons and often entered into asylum through a quite regular procedure. As a result of cultural or other factors some people may have felt they had a claim or expectation of asylum or resettlement elsewhere. ${ }^{53}$

Indeed, if one looks back at the ebb and flow of national attempts to secure boundaries and to regularize the flow of aliens across them, it is striking how little these efforts seem uniform or principled. ${ }^{54}$ Grants of asylum were not originally thought of as discretionary privileges of a sovereign or as strictly humanitarian acts of grace. They were conceived of in this way only after refugee status was legalized at the international level in contrast to asylum. The attempt to characterize them as the "progressive triumph of sovereign political discretion" is misguided. Rather, one finds episodic efforts in various places to control particular population flows, often for economic, racial or political reasons. 55

52. See 2 A. Grahl-Madsen, supra note 2, at 57-68; Report on the Regional Seminar on Protection of Refugees in Latin America (1979), (HCR/120/1/80 GE.80-0587 at $7 \mathrm{ff}$ ).

53. See infra notes 88-117. See also R. Plender, supra note 4, at 38ff; T. Veiter, Funf und zwanzig Jahre Fluchtlingsforschung (1975); W. McNeill and R. Adams, Human Migration, Patterns and Policies (1978); Commission Internationale d'Histoire des Mouvements Sociaux et des Structures Sociales, Les Migrations Internationales de la Fin du XVIIIe Siecle a Nos Jours (1980).

54. See R. Plender, supra note 4, at 38-93.

55. Thus the American-generated alien legislation in response to particular immigration waves from China or Europe. $1 d$. at 48. Other European regularizations of what now would be seen as asylum claims were generated by desire to associate or disassociate one's regime from various political upheavels occurring elsewhere in the 1830 s, late 1840 s and thereafter. Id. at 42-50. The basic approach was flexible admission, particularly for individuals seeking refuge. $I d$. The elaborate alien legislation common early in this century represented far more often a movement towards regulation and preference than exclusion. Id. One could call this the progressive assertion of an absolute sovereign prerogative to exclude aliens which no state has ever fully recognized, but such a description would say more about one's theory of sovereignty than about historical reality. In fact, restrictive legislation was both politically exclusionary insofar as it reflected changing waves of consciousness about natural security, and politically receptive in its treatment of asylees and others. It was both culturally exclusionary and culturally inclusionary in its racial overtones and recognition of the necessity to admit 
Moreover, asylum was not thought to be exclusively either national or international. Asylum was the product of national law and involved the deprivation and reacquisition of national jurisdictional protection. In the international context, one spoke only of respecting the asylum granted elsewhere or of empowering states to grant asylum. At the same time, however, asylum was the product of internationally recognized jurisdictional limits. Similarly, the protection that asylum implied was both legal and political and the decision to grant or withhold it was both a political and a legal decision. Both the protection and the decision to grant it were municipal decisions which had to be respected. Although asylum expressed sovereign autonomy, it developed in response to a growing community of sovereign interest in mutual respect for boundaries. It was not possible to distinguish refugee from asylum as international was distinguished from national, legal from political, or cooperative from national and autonomous. Asylum as a status and a condition reflected each of these elements. As a result, although there was a sharp difference between refugee and asylum in the high positivist period there was no disjuncture between them. The differences between refugee and asylum law expressed the difference between two national protections. In between these was no space for an independent international competence.

\section{The Early Contemporary Position}

The modern approach to refugee and asylum differs greatly from that of both the early period and the era of high positivism. This difference is a byproduct of the growth of a distinctive international legal competence to protect refugees, which originated in what had been a temporal gap between becoming a refugee and receiving asylum..$^{56}$ In the nineteenth century there could be no temporal gap between flight and arrival. One was always located within some national jurisdiction. With the development of national immigration restrictions and nationalization procedures, however, some individuals found themselves in a legal limbo-either stateless or temporarily without acceptance by any sovereign. During such unavoidable temporal gaps in the assimilation of persons to particular sovereigns the international

family members or members of traditionally linked nationalities or ethnic groups. These historical trends were constituted of an responsive to a far wider society of specific national internal commitments, bilateral agreements, cultural or political sympathies, and the like than a uniform principle of "discretion" would suggest. Everywhere, at all times, there was some receptive openness, if only for reasons of commerce and political solidarity, and the restrictive movement was more a matter of legal and procedural regularization than the rhetoric of "sovereign political discretion" suggests. Id.

56. See G. Goodwin-Gill, supra note 2, at 127-129; 1 A. Grahl-Madsen, supra note 2, at 122-141. 
organizations of the early contemporary era filled in for states. The early work of international refugee protection was procedural and technical, involving issuance of travel documents and so forth. 57

Although the international community might have assimilated individuals passing between refugee and asylum status to a single state - perhaps to the Vatican or to the state of presence - it developed international organizations for this purpose. However, the protection which an international organization might provide a refugee was not thought to be identical to that provided by a state. Unlike protection from a sovereign, international refugee protection would be "non-political," humanitarian and legal. Moreover, it would be international. 58

This set of distinctions between the U.N.H.C.R. and sovereign authority generated an international substantive vision of refugee status and permitted the procedural standardization of the treatment of refugees. 59 Refugee became an international legal status rather than simply the factual situation prior to asylum. Refugees were now in legal limbo between disconnection from one state and reattachment to another. 60 The person in limbo between national protections was no longer simply "stateless" but might also be a "refugee," and a separate branch of law developed which elaborated the distinctive qualities of refugee status. Moreover, a separate institutional intervenor was authorized to assist persons so situated.

This development was not without costs. The space for international institutional action was created not only by contrast to national competence, but also by excluding concern with the causes and solutions of refugee flows from the U.N.H.C.R.'s competence. The Protection Division's attempts to distinguish the refugee simultaneously from both a protected national and an assimilated asylee were in tension with its efforts to establish comprehensive competence over refugee affairs. Initially, the U.N.H.C.R. confined its protection work to the refugee temporally or geographically in transit from one municipally granted status to another. This limited role fit with the vision of international protection as a replacement for a lost sovereign function. However, as protection became increasingly a substantive U.N.H.C.R. func-

57. This early conception finds some voice in the U.N.H.C.R. Statute. The Commissioner is to protect him who is "unwilling to avail himself of the protection of the government of the country of his nationality." Statute of the U.N.H.C.R., supra note 8, at art. 6(a) (ii). "Protection," like "asylum" and "refugee," was still a national conception. In this light it is easy to understand what now seems an odd disjuncture within the Statute between the individual determination of refugee status and the notion that the U.N.H.C.R. shall deal primarily with "groups" of refugees. So long as the work is procedural, it, like national sovereign protection, applies to groups (citizens in the national context, refugees for the U.N.H.C.R.) on an individual basis. Id. at art. 2.

58. Id. arts. 1-2. See G. Goodwin-Gill, supra note 2, at 127-135.

59. These developments are considered in most standard histories of refugee law. See, e.g., 1 A. Grahl-Madsen, supra note 2.

60. See 1 A. Grahl-Madsen, supra note 2, at 142ff; G. Goodwin-Gill, supra note 2, at $5 \mathrm{ff}$. 
tion and as refugee law developed, the tensions within protection between establishing an independent U.N.H.C.R. competence and protecting refugees comprehensively grew clearer.

Moreover, the development of a distinctive U.N.H.C.R. competence for "refugees" altered notions of asylum and of the relationship between asylum and refugee law. First, the establishment of a refugee status differentiated by its relatively legal and cooperative quality strengthened the perception that asylum was a matter of national political autonomy. Second, and more important, asylum came increasingly to be thought of as a status to be granted rather than a condition to be enjoyed. In this way, asylum came paradoxically to seem more like refugee law. The difference lay in the grantor. The U.N.H.C.R. would grant or at least oversee the granting of refugee status on the basis of international legal standards. The national sovereign would grant asylum on the basis of domestic political calculations. For the first time, commentators began to focus on the discretion to grant asylum rather than upon the condition of enjoying the asylum afforded by exclusive territorial jurisdiction.61

These two changes in the approach taken by international lawyers to asylum are difficult to reconcile. Asylum seemed simultaneously to become both more formal and less legal. This shift has its origins in the institutional vantage point of protection officers. International lawyers involved in refugee protection, after legalizing refugee status, tended to imagine that if the refugee did not have a "right" to asylum he would have "no right" to asylum and would legally remain a "refugee." This legal limbo seemed somehow to imply an actual physical limbo in which the refugee would be subject to the whims of national authorities. International lawyers thus fashioned an asylum status in the image of their internationalized notion of the refugee. ${ }^{62}$ Exaggerating the doctrinal disjuncture between refugee and asylum and portraying asylum as an internationally uniform matter of national whim run counter to the history and doctrine of asylum. In many places "asylum" status has been legalized and in many places the appellation "refugee" is primarily of political significance. ${ }^{63}$ Often the consequences of "asylum" are legalized and may even be compulsory. ${ }^{64}$ Elsewhere the procedures for considering asylum requests and even the standards to be applied may be legislated. Overall, the granting of asylum takes place within an in: ternational context, and is responsive to political, cultural and legal ties.

The new disjuncture between "asylum" and "refugee" was much more difficult to bridge than the difference posited by traditional high positivism.

61. See, e.g., 2 A. Grahl-Madsen, supra note 2, at $22 \mathrm{ff}$.

62. See supra section V; 2 A. Grahl-Madsen, supra note 2, at 79-109; A. Grahl-Madsen, Asylum, supra note 24, at 69-80.

63. See 2 A. Grahl-Madsen, supra note 2, at $109 \mathrm{ff}$.

64. Id. See also G. Goodwin-Gill, supra note 2 , at $165 \mathrm{ff}$. 
One was no longer the mere absence of or prerequisite for the other. They were now statuses conceptualized on distinctly different levels. At the same time, the internationalization of refugee status was not a return to an imagined prepositivist world in which sovereigns were more cooperative. This new concept of refugee could sustain its special quality only by contrast to state asylum policy, viewed now as primarily political and autonomous. Although this change was part of a much larger legalization and internationalization of international life, it set the U.N.H.C.R. in continual tension with itself. This tension has required, and by and large produced, elaborate doctrinal efforts to reconnect normatively what had been rent asunder doctrinally: the statuses of being a refugee and having asylum.

It has seemed, paradoxically, that the more authority the U.N.H.C.R. received to care for refugees, the more distant seemed internationalization of a solution to the refugee's plight. ${ }^{65}$ Treating asylum as the discretionary other of a uniform refugee status not only closes the U.N.H.C.R. out of the asylum business, it also somewhat paradoxically downplays the extreme differences among national and regional asylum practices. Confining the U.N.H.C.R. mandate to refugees and defining refugees more formally than asylees not only risks limiting the Protection Division's scope of action, but prevents it from seeing opportunities for cooperation. Undoubtedly there are many complex causes for the hardening of national hearts, including more massive refugee movements, internal economic conditions and an increase in refugee movement across boundaries of culture, class and race. ${ }^{66}$ Nevertheless, there is a relationship between increasing national autonomy and the expanding U.N.H.C.R. mandate. The more one thinks of refugees as international, the greater is the disjuncture posed between asylum and refugee status, and the easier it is for a sovereign to grasp the opportunity for sovereign discretion leaving the U.N.H.C.R. to worry about refugees.

\section{Recent Doctrinal and Institutional Evolution}

To a great extent, the U.N.H.C.R. has been able to overcome the difficulties created by these doctrinal and institutional consequences of its early development. As the U.N.H.C.R. mandate has broadened, the distinctive otherness of asylum has been softened. ${ }^{67}$ Whether one traces the changing

65. The hardening of national attitudes has been seen and commented on a number of times, but its most dramatic illustration was the failure of the 1977 United Nations Conference on Territorial Asylum. See A. Grahl-Madsen, Asylum, supra note 24, at 61-68; G. Goodwin-Gill, supra note 2, at 109-114; Dadzei, "Conference on Territorial Asylum, Division Report," (14 February 1977).

66. See A. Grahl-Madsen, Asylum, supra note 24; Gilbert, "Right of Asylum: A Change of Direction," 32 Int'l \& Comp. L. Q. 633 (1983); Martin, supra note 14.

67. See L. Sohn, supra note 32. 
U.N.H.C.R. mandate through the documents of the General Assembly, ECOSOC or the U.N.H.C.R. Executive Committee, one cannot help being struck by the progressive abandonment of the rigid distinction between refugee and asylum which characterized early efforts to mark off a consistent and principled identity for the U.N.H.C.R.

In the immediate post-war period, the General Assembly addressed what it termed the "problem of refugees and stateless persons," instructing the U.N.H.C.R. to "promote . . the most suitable solution" to this problem by providing "for the protection of refugees and displaced persons." 68 Although the General Assembly began by "recognizing the responsibility of the United Nations for the international protection of refugees" it did not do so by separating an international refugee status from a national solution. Asylum was not mentioned. Rather, one characteristically spoke of a solution to the "problem of refugees" which would involve their "voluntary repatriation" or their "assimilation within new national communities." 69 The important point about these early documents is that they envisioned a unified field of jurisdiction, protection and solution. Although one could characterize the solutions they foresaw as matters of national discretion, these documents seem to have envisioned a role for the U.N.H.C.R. in fashioning and promoting them. The international formalization of the U.N.H.C.R. mandate with its correlative references to national solutions had not yet taken hold. These documents appealed to states to "assist the IRO in its efforts to resettle refugees" rather than to grant asylum. ${ }^{70}$ They referred to a process of "assimilation of refugees in the countries of their residence" in which states and the U.N.H.C.R. were given equal billing. ${ }^{71}$

By the early 1960s, however, this vision had eroded. The notion of "assimilation" was replaced by the words "resettlement and integration," implying an international and a national process. ${ }^{72}$ The word asylum appeared for the first time in General Assembly resolutions relating to refugees in 1965, when reference was made to the "large numbers of refugees [who are] being obliged to leave Hungary and to seek asylum in neighboring countries." 73 There is some ambiguity in the documents: states were still not asked to grant asylum. Indeed, "care and resettlement" rather than asylum was the envisioned solution. ${ }^{74}$ The political significance of the Hungarian refugee flow implied by use of the word asylum was not yet discontinuous with inter-

68. G.A. Res. 319, U.N. Doc. A/1251, at 36 (1949).

69. G.A. Res. 319, Annex 4(c) at 37, U.N. Doc. A/1251 (1949).

70. See, e.g., G.A. Res. 430, 5 U.N. GAOR Supp. (No. 20) at 49, U.N. Doc. A/1775 (1950).

71. See, e.g., G.A. Res. 638, 7 U.N. GAOR Supp. (No. 20) at 27, U.N. Doc. A/2361 (1952).

72. See, e.g., G.A. Res. 728, 8 U.N. GAOR Supp. (No. 20 B) at 16, U.N. Doc. A/2361 (1953);

G.A. Res. 925, 10 U.N. GAOR Supp. (No. 19) at 13, U.N. Doc. A/3116 (1955).

73. G.A. Res. 1006 (ES-11), 11 U.N. GAOR Supp. (No. 1) at 3, U.N. Doc. A/3355 (1956).

74. G.A. Res. 1129, 11 U.N. GAOR Supp. (No. 17) at 63, U.N. Doc. A/3572 (1956). 
national involvement. Nevertheless, the word asylum was not used in subsequent requests that the U.N.H.C.R. protect and assist refugees from China, Angola or Algeria.

By 1960, the disjuncture between "seeking a permanent solution" (an international legal matter) and "integration in countries of asylum" (a national political matter) had become routine. The U.N.H.C.R. was to facilitate the first and national authorities would be called upon to grant the other. ${ }^{75}$ Just as the international legal mandate of the U.N.H.C.R. reached its most formal elaboration, the word "asylum" began to be used to characterize the solution envisioned. The U.N.H.C.R. was to "promote permanent solutions . . by facilitating the voluntary and rapid settlement of these refugees in the countries of asylum ... taking into account the specific requirements existing in each country of asylum." 76 On this and other occasions during the sixties, the formal extension of the U.N.H.C.R. mandate was accompanied by increasing reference to the solution of national asylum. For the first time, international protection addressed more than a procedural and temporal gap in national assimilation. Yet the ultimate solution was now emphasized to be a matter of national discretion. A disjuncture appeared between determining the jurisdiction of the U.N.H.C.R. and ascertaining its capacity to achieve solution. Where a single paragraph had previously sufficed, encouraging the U.N.H.C.R. and states to become involved in and solve a particular refugee problem, there were now customarily two paragraphs: one addressed to the U.N.H.C.R., expanding its mandate or asking for the use of its "good offices" with respect to a group of refugees, and one addressed to states requesting that they assist the U.N.H.C.R. and provide asylum or solution. ${ }^{77}$

It is significant that at this stage asylum came to be used to refer not just to what refugees might receive but to a solution which seemed particularly suited for refugees, as if to confirm through the national solution requested that the individuals had been refugees. This usage of the term heightened the apparent tension between the political nature of solution and the humanitarian/legal nature of the U.N.H.C.R. mandate. At the same time, it added to the tension between the injunction in the Statute that the U.N.H.C.R. concern itself with "groups" and the individualized refugee definition which defined its competence. It is at this point that we can see most clearly the relationship between the concept of asylum and the development of sharp perceived discontinuities between international and national protection, the U.N.H.C.R. jurisdiction and national solution, individual criteria and collective responses.

75. See, e.g., G.A. Res. 1673,16 U.N. GAOR Supp. (No. 17) at 28, U.N. Doc. A/5100 (1961); G.A. Res. 1959, 18 U.N. GAOR Supp. (No. 15) at 42, U.N. Doc. A/5515 (1963).

76. G.A. Res. 2197, 21 U.N. GAOR Supp. (No. 16) at 48, U.N. Doc. A/6316 (1966).

77. See, e.g., G.A. Res. 2399, 23 U.N. GAOR Supp. (No. 18) at 42, U.N. Doc. A/7218 (1968). 
Once sharpened in this way, however, the further development of the U.N.H.C.R. mandate began to blur these distinctions. We might think of the organization as having come of age, first asserting its independence vigorously, formally disassociating itself from national political matters in a principled fashion and then maturing to adopt a more eclectic and flexible style. But this new style was not a return to the earlier period of undifferentiated attention to jurisdiction and solution, international law and national discretion. This new approach is best evidenced by the contemporary relationship between the U.N.H.C.R. mandate and "asylum."

Throughout the 1970s and 1980s, General Assembly resolutions commenting upon the High Commissioner's Report or drawing the attention of the Protection Division to a new refugee situation have differentiated their inclusion of new refugees under the U.N.H.C.R. mandate from their calls for solution. It has remained true that the mandate has primarily been viewed as an international matter, extendable to refugees and "displaced persons," and that solutions have been thought of as matters of national discretion in whose arrangement the U.N.H.C.R. could act only as "promotor" or "facilitator." The concept of asylum, as it has crept into these documents during the past fifteen years, has been used disproportionately to characterize solutions rather than the expansion of U.N.H.C.R. competency.

But the story is a bit more complicated. Although the term "asylum" was not used to refer to the situations in East Pakistan, the Sudan or Djibouti, ${ }^{78}$ it was used after 1976 to characterize South African student refugees in neighboring countries who were assisted by the U.N.H.C.R. ${ }^{79}$ The use of the word asylum, like the characterization "student," might be thought to reflect an attempt to emphasize that these individuals were indeed refugees rather than soliders by referring to the national solution usually seen to be appropriate for refugees (instead of, for example, "safe haven"). However, when contrasted to other African situations, the use of asylum may reflect a greater sensitivity to the political nature of their flight; a sensitivity which, while placing them more closely within the definition of refugee than would "displaced persons," seems, in the context of a mandate grown legal and formal, to threaten the "humanitarian" nature of the U.N.H.C.R.'s role. It is, in other words, not clear whether the word asylum as used here expands the U.N.H.C.R.'s mandate or merely indicates that the individual concerned is indeed within the mandate.

Under the traditional positivist notion of the relationship between refugee and asylum, use of the word asylum would place these students

78. See, e.g., G.A. Res. 2790, 26 U.N. GAOR Supp. (No. 29) at 84, U.N. Doc. A/8429 (1971); G.A. Res. 2958, 27 U.N. GAOR Supp. (No. 30) at 65, U.N. Doc. A/8730 (1973); G.A. Res. 35/181, U.N. GAOR Supp. (No. 48) at 200, U.N. Doc. A/35/48 (1981); G.A. Res. 35/182, 35 U.N. GAOR Supp. (No. 48) at 200, U.N. Doc. A/35/48 (1981).

79. See, e.g., G.A. Res. 32/119, 32 U.N. GAOR Supp. (No. 45) at 142, U.N. Doc. A/32/45 (1977). 
within the definition of refugee, although post-hoc. This conception of asylum would also have terminated the U.N.H.C.R.'s involvement by signifying renewed national assimilation. As a result we would need to see its use here as an expansion of the U.N.H.C.R.'s mandate to participate more in what had been seen as part of "national solutions." On the other hand, in the new international legal vision of the mandate, expanded only on humanitarian grounds to "displaced persons," the use of the word asylum in connection with the South African students represents a blurring of the distinction between the legal and political, the national and international. In either case, we see an expansion of the U.N.H.C.R.'s mandate: either to the period beyond reassimilation where that reassimilation seems, for some reason insufficient as a substantive solution, or to matters which cannot be defined strictly in terms of international legal categories. Both of these conceptions are sustained by other texts referring to the South African situation, which use "asylum" to refer to the "refuge" or "relief" which these students sought and received in neighboring countries.

It seems likely that using the term "asylum" in connection with South African students primarily signifies that they are to be considered to have been refugees. The difficulty created by this importation of the traditional concept of asylum once refugee protection has been internationalized is to account for continued U.N.H.C.R. involvement. This seems to have been done by using asylum to signify a partial or temporary or internationally unsatisfactory solution; exactly the opposite of the original complementary vision of the relationship between refugee and asylum as well as of the independence and significance of asylum. Somewhat paradoxically, the move to think of asylum as exclusively political and domestic has undermined its claims to be a definitive solution. Here we see the beginning of a backlash against the exclusivity of asylum which had been generated by the internationalization of refugee law. This backlash begins the reassertion of an ongoing international involvement in the conditions and durability of asylum. This is a reassertion which I explore in greater depth when considering asylum and solution. ${ }^{80}$

More dramatic has been the use of the term "asylum-seeker," primarily in Executive Committee documents, to describe the so-called boat-people in Southeast Asia who are of concern to the U.N.H.C.R. ${ }^{81}$ Under the traditional view of asylum and refugee as complementary terms, neither of which delimited a status, the substitution of "asylum-seeker" for "refugee" would be insignificant except as it might signify (by use of the word "seeker") a move

80. It is important at this point to avoid the temptation to seek a doctrinal reconciliation of this budding reinternationalization of asylum with rigid categories of international and national protection such as would be possible if one implied in the texts a new equally rigid notion of "temporary" asylum or "first" asylum. See supra section V.

81. See, e.g., Report of the Executive Committee of the U.N. High Commissioner for Refugees, U.N. Doc. A/12A/31/12/Add.1 (1976). 
from an objective to a subjective measure of the need for reassimilation to a new state. It seems possible that this language was chosen to avoid commentary on the validity of the claims by boat-people to refugee status. Yet after the internationalization of refugee status and the concomitant transformation of asylum into a discretionary status, this synonymy no longer seems logically possible.

If the loss/reacquisition of natural protection is no longer the sine qua non of being a refugee-asylee and national discretion is, the term asylumseeker could encompass everyone from displaced persons and economic migrants to exiles. Once split in this way, using asylum to define the mandate threatens to allow a liberated tail to wag the U.N.H.C.R. dog. Seen this way, the increased use of "asylum-seeker" might paradoxically indicate the simultaneous elimination of an international refugee status and either a massive expansion of the U.N.H.C.R. mandate or dependence upon national authorities for determination of its mandate. Even if one assumes that the term was used precisely to indicate that these people were squarely within the U.N.H.C.R. mandate (and not merely displaced persons or war victims), the use of "asylum-seeker" to accomplish that connotation in an era of internationalized refugee status would imply a simultaneous expansion of the mandate and a withering of the distinction between the mandate and solution that the disjuncture of asylum and refugee had upheld. That the use of the term indicates a particular sort of mandate expansion is also indicated by the simultaneous extension of "protection" from a legal matter to a physical matter of insuring the safety of these individuals, calling for new forms of protection work (such as the anti-piracy program) incompatible with traditional notions of a rigid distinction between international legal protection and solution or cause.

This expansion of the U.N.H.C.R.'s mandate through use of the term "asylum" to describe new situations produces confusion because it draws simultaneously upon a traditional notion of the logical difference between refugee and asylum and upon a notion of the separation of international law and municipal politics. Indeed, the expansion works because it is able to draw on both notions of "asylum" without falling to either extreme. "Asylumseeker" becomes a floating term between the international legal and domestic political terms "refugee" and "asylum" by reawakening the sense that this difference need not be such a rupture. The result is to codify the mandate's expansion without relying upon the notion of "displaced persons" by exploiting a backlash against the international confusion. The Executive Committee's 1981 conclusion demonstrates this maneuver in the following construction of a category of "asylum-seekers" both larger than and smaller than "refugee":

1. The refugee problem has become particularly acute due to the increasing number of large-scale influx situation in different areas of the world and espe- 
cially in developing countries. The asylum seekers forming part of these large-scale influxes include persons who are refugees within the meaning of the 1951 United Nations Convention and the 1967 Protocol relating to the Status of Refugees or who, owing to external aggression, occupation, foreign domination or events seriously disturbing public order in either part of, or the whole of their country of origin or nationality are compelled to seek refuge outside that country. ${ }^{82}$

After this breathtaking exploitation of the doubled referential association of asylum and refugee, the U.N.H.C.R. is asked to direct its attention to "asylum-seekers." By 1983, the backlash is complete and the terms "refugee and asylum-seeker" have become a joined pair in Executive Committee parlance, ${ }^{83}$ downplaying the disjuncture between a national and international status. As we might expect, the calls for action and expressions of concern are again united in single paragraphs referring to national and international laws and practices. This consolidation of the expanded competence of the U.N.H.C.R. protection division, achieved by slowly excluding, changing and reintroducing the concept of asylum should be quoted in full:

The Executive Committee:

(b) noted that the High Commissioner's international protection function included, in addition to promoting the development and observance of basic standards for the treatment of refugees, promoting, by all means within his competence, measures to ensure the physical safety of refugees and asylum-seekers . . . (e) noted also with concern that the exercise of the High Commissioner's international protection function has been rendered more difficult in many areas of the world by restrictive trends relating to the granting of asylum and determination of refugee status . . .

(j) recognized the importance of developing standards of protection by maintaining a constant dialogue with Governments, non-governmental organizations and academic institutions and of filling lacunes in international refugee law, particularly as regards asylum-seekers whose status has not been determined and as regards the physical protection of refugees and asylum-seekers . . .

(l) recognized the essential need for the exercise of the High Commissioner's international protection function to be facilitated by the co-operation of Governments in granting asylum, in providing the durable solutions of resettlement in local integration and in creating conditions favorable to and promoting voluntary repatriation, which whenever, appropriate and feasible, is the most desirable durable solution for refugee problems, such co-operation should also include fostering in public opinion a deeper understanding of the special needs of refugees and asylum-seekers. ${ }^{84}$

82. Protection of Asylum Seekers in Situations of Large-Scale Influx, No. 22 (XXXII) Executive Committee Conclusions (1981).

83. See, e.g., Report of the Executive Committee of the U.N. High Commissioner for Refugees, U.N. Doc. 12A/A/37/12/Add.1 (1982).

84. Report of the Executive Committee of the U.N. High Commissioner for Refugees, U.N. Doc. 12A/A/38/12/Add.1 (1983). 
The concept of "asylum," now woven back into discussions of the U.N.H.C.R. mandate, has been helpful in overcoming the initial isolation of the U.N.H.C.R. in an international legal world, an isolation which was itself originally achieved by the appropriation of "refugee" for and the exclusion of "asylum" from mandate discussion.

\section{E. Conclusions About Jurisdiction}

The U.N.H.C.R.'s institutional identity and the distinctiveness of jurisdictional inquiry have been achieved and sustained in part by differentiating the identification processes for refugees and potential asylees not merely temporally, but also conceptually, as law and politics, international and national, cooperation and autonomy. This modern conceptual effort contrasts sharply with earlier historical visions of the relationship between the institutions and doctrines of refugee and asylum. Indeed, the disjuncture between refugee and asylum appeared as international institutions began to develop what were seen as special competencies to deal with refugees. Although this change has strengthened the hand of the U.N.H.C.R. and other institutions, it has simultaneously implied a national license with respect to asylum which takes solution to the plight of refugees ever further from the U.N.H.C.R. competence just as the legalization of jurisdiction, with its focus on refugee as a legal status, removed the U.N.H.C.R. from the causes of refugee flows. There is, then, a reciprocal relationship between the U.N.H.C.R.'s expanding competence and separation from issues of cause and solution, and its use of asylum.

As might be expected, the broadening of the U.N.H.C.R. mandate in recent years has been accompanied by new approaches to asylum which have begun to overcome its segregation in national discretion. These efforts have drawn upon asylum's historical association with international law, sovereign. cooperation and mutual respect. Woven back into discussions of the U.N.H.C.R.'s mandate, asylum has been helpful in overcoming the U.N.H.C.R.'s isolation in a Eurocentric and legalistic institutional world. As a result, the U.N.H.C.R. mandate can now be said to apply to asylum situations, in the sense that an opportunity has been generated for the U.N.H.C.R. to develop a more extensive partnership with states in this area so long as that does not mean attempting to legalize or internationalize the institution of asylum.

To say that the U.N.H.C.R. mandate now extends to asylum situations is to recognize that mandate discourse never produced an institutional identity as exclusively legal and universal as might have been suggested. Asylum was never as uniformly national, political or discretionary as it may have been seen to be. Merely saying this suggests a willingness to get around the constraints of those sharp distinctions to provide new partnerships between na- 
tional and international protection. These new roles will not roll back the achievements represented by the internationalization of refugee law any more than they will capture sovereign discretion and legalize national politics. They suggest, rather, a determination to operate flexibly in different situations and national contexts, to participate in formation of comprehensive solutions, to continue protection after the granting of asylum and commence inquiry before the putative withdrawal of national protection by flight.

By way of illustration, we might consider the current U.N.H.C.R. response to the problem of orbit refugees in Europe which represents one form that such a new protection role might take. Oversimplified, "orbit refugees" are people who seek asylum in one country after another, never being returned to their country of origin but never being durably resettled either. ${ }^{85}$ Under older visions of the U.N.H.C.R. mandate, one might have contrasted two divergent strategies. On the one hand, these people seem outside the mandate: they are in no danger of being returned to a country where they fear persecution and their difficulty results from divergent national asylum practices and matters of exclusive national political competence. On the other hand, those wishing the U.N.H.C.R. to get involved would seek to bring these situations into the international legal world of the U.N.H.C.R., perhaps by legalizing or internationalizing asylum. Efforts to help these individuals would be turned into a struggle against the otherness of asylum. The new approach recognizes these two visions as insufficiently flexible. The U.N.H.C.R., by working with governments to promote harmonization of asylum procedures, either by mutual recognition, or adoption of uniform criteria, has extended its mandate of protection to a situation which involves a mixture of law and politics, at the international level. Recognizing that the problem is neither too little international law nor too much national discretion, but rather a failure to agree upon a way of ascertaining who will bear the burden for asylum seekers in Europe, the U.N.H.C.R. can and has worked to assist and achieve protection for these individuals. ${ }^{86}$

This new role for the U.N.H.C.R. was acknowledged, although not warmly embraced, by the Executive Committee in 1980 when it stated:

that while there was a need to develop legal concepts relating to international protection in the light of the special conditions prevailing in different regions, this

85. See Melander, "Refugees in Orbit," 16 (25) AWR Bulletin 1-2:59 (1978); Council of Europe, Committee of Minister's Recommendation No. R(81)(16) on the Harmonization of National Procedures Relating to Asylum (5 November 1981); A. Grahl-Madsen, "Refugees in Orbit -Some Constructive Proposals," Int'] Inst. of Hum. L. Roundtable on Refugees in Orbit-Florence 4-6 (December 1979).

86. See, e.g., "Asylum: Refugees Without an Asylum Country," Note presented to the SubCommittee of the Whole on International Protection of the U.N.H.C.R. Executive Committee (1979), contained in HCR/PRO/3 at 45. 
should not detract from the absolute character of the fundamental principles already established in the field. ${ }^{87}$

The dilemma posed for the U.N.H.C.R. protection officers is to develop access to asylum without toppling the Protection Division's legitimized identity. That can be and has been done. To do so, however, the tendency to develop the mandate by alternately excluding and co-opting asylum will need to be overcome.

\section{SOLUTIONS FOR REFUGEES}

\section{A. Asylum Law, Refugee Law and U.N.H.C.R. Solutions}

The progressive development of a distinctive competence for the U.N.H.C.R. was associated with a growing disjuncture between refugee and asylum - the former appearing increasingly to be an international legal status, the latter a national discretionary political status. Although this disjuncture has diminished as the U.N.H.C.R.'s institutional identity has changed, the elaboration of a distinctive legal mandate for the U.N.H.C.R. has tended to limit consideration of both asylum and solution. Although the attempt to facilitate solutions for mandate refugees, to the extent it has been a Protection Division function, seems always to have involved the protection officer in considering the terms of asylum granted, the disjuncture between refugee and asylum, like the split between discussions of the mandate and of solution, has tended both to diminish the U.N.H.C.R.'s input into the formulation of solutions for refugee problems and, more importantly, to channel their remaining input into solutions which are procedural, legal and universally applicable. These constraining and Eurocentric tendencies were most characteristic of early U.N.H.C.R. work. They reflect neither the historical and doctrinal nature of asylum nor the Protection Division's capacity for participation in providing solutions. As discourse about solutions has shifted from a primarily European focus, legal scholars and United Nations lawyers have come to treat asylum in a more creative fashion. ${ }^{88}$

In a way, the odd thing is that international scholars and lawyers should ever have elaborated the rights and duties triggered by refugee status and the content of "asylum" so disparately. ${ }^{89}$ Both discussions concern the results

87. Report of the Executive Committee of the U.N. High Commissioner for Refugees, at (d), U.N. Doc. 12A/A35/12/Add.1 (1980).

88. For a discussion of solutions in its historical context, see $1 \mathrm{~L}$. Holborn, Refugees, supra note 3 , at $321-556$.

89. This disjuncture has often been recognized explicitly. See, e.g., G. Goodwin-Gill, supra note 2, at 207 (noting the "divorce" between refugee status and asylum "in the sense of a lasting solution"). These are considered distinctly, not only by Goodwin-Gill, but by most commentators. See A. Grahl-Madsen, supra note 2 (devoting separate volumes to the two subjects). 
for displaced persons of being "protected," either by recognition as a refugee or by grant of asylum. Still, these two topics are generally discussed separately and, more importantly, differently. Discussion of the protection due refugees sounds legal and international: one speaks of "rights" and "duties" triggered by international recognition of one's refugee status. The perquisites of being a refugee are legal claims which derive from recognition of a legal status. ${ }^{90}$ By contrast, the perquisites of the asylee are diverse and depend upon the particular constellation of municipal prerogatives which conspired to grant asylum. ${ }^{91}$ To define asylum has been to describe a condition of little uniformity while to discuss refugee status has been to elaborate a body of international norms.

The difference between these two discussions about solutions is in some ways similar to the difference between asylum and refugee concepts in mandate discourse. Protection officers discuss solutions, as they discuss the mandate, on two distinct levels: one international and legal; the other national and political. In another sense, however, the difference between asylum and refugee discourse is not as great here. Rather than opposing a jurisdictional discussion on one level with a remedies discussion on another, lawyers engaged in the international protection of refugees pursue two different discussions addressing the same subject: what happens to people who have been refugees. It should not be surprising that these two discourses blend into one another, or that protection officers, in pursuing solutions, should hesitate far less to bring asylum within their ken. In solutions discourse, institutional identity is far less dependent on the exclusion of asylum than in mandate discourse. That the conditions of asylum receive attention in this way does not indicate, however, that the basic distinction between the two levels has been abandoned. Indeed, one might even say that the ability to blur the boundary when considering solutions depends upon its strict observance in mandate discourse.

In any case, the difference between asylum and refugee takes a different form in solutions discourse. In mandate discourse, both asylum and refugee were treated as legal statuses, granted at different levels, one within and one without the jurisdiction of the U.N.H.C.R. Although in solutions discourse, refugee and asylum are both seen to generate solutions, although on different levels, only refugee is regarded as a status, while asylum is more of a condition. These relations are confusing because mandate discourse differentiated refugee and asylum (for purposes of creating an independent U.N.H.C.R. legal jurisdiction) in part by treating them both as statuses,

90. See 1 A. Grahl-Madsen, supra note 2, at $73 \mathrm{ff}$. Grahl-Madsen, like other commentators, concentrates almost exclusively upon the prerequisites to becoming a refugee and the loss of refugee status rather than upon the prerequisites of being a refugee. This emphasis reflects the difficulty of reconnecting an international doctrinal style discourse with solutions per se. Compare G. Coles, supra note 33; and D. Luca, supra note 33.

91. See 2 A. Grahl-Madsen, supra note 2; G. Goodwin-Gill, supra note 2, at 165ff, 209. 
granted by different authorities. Solutions discourse, on the other hand, pursuing U.N.H.C.R. involvement in both asylum and refugee matters, stresses that they are different; that asylum is a condition and refugee a status.

Given the U.N.H.C.R.'s overriding legal self-image, this paradox facilitates the U.N.H.C.R.'s involvement in asylum work. By de-legalizing asylum somewhat in the solutions context, the U.N.H.C.R. can either treat its involvement in asylum as a relatively underground non-legal activity or seek to re-legalize asylum on the international level. When the protection officer expresses his concerns about asylum and solutions in this way, he reinforces the disjuncture between two levels and types of institutional activity. This disjuncture continues to structure the approach he takes to refugee status, to the conditions of asylum and to the relationship between the two in the solutions context.

The presence of two distinct branches of solution discourse presents the protection officer with a choice: to pursue either what is perceived as a national and political approach, agitating for more favorable asylum conditions in particular situations, or to take what seems the high road of international normative exhortation, urging respect for norms of refugee treatment. If these two paths were not seen to be differentially international and political, it would be easy to imagine following both. As it is, pursuing both creates either an uneasy feeling about the institutional legitimacy of doing either or an oddly split institutional practice. Moreover, since the U.N.H.C.R.'s identity has traditionally been defended on international non-political grounds, the asylum branch of solution discourse, imbued as it is with a political and municipal flavor, remains the poor half-brother of the refugee branch. The first consequence for solution discourse of the disjuncture between asylum and refugee, then, is the impoverishment of national, political solutions and the privileging of international legal approaches.

This approach to solutions begins with a traditional picture of the U.N.H.C.R. as a stand-in sovereign protector of refugees whose protection work should be respected by other sovereigns. ${ }^{92}$ The high road to solutions thus begins by elaborating the procedural protection activities of the U.N.H.C.R. into attributes of refugee status. Thus, because the U.N.H.C.R. is entitled to issue travel documents or provide consular services, a person with refugee status might be thought to be entitled to have his travel documents respected. Solutions are deduced from jurisdiction.

In this approach, the conditions for cessation of U.N.H.C.R. protection constitute the refugee's entitlements in his country of resettlement. Thus, international legal documents regulating refugee status contain extensive provisions about legal reassimilation in a national context: provisions regulating

92. The most sophisticated development of this approach which I have seen is G. GoodwinGill, supra note 2; see also Aga Khan, supra note 31. 
legal personality, access to courts, exemption from reciprocity principles limiting treatment of aliens, conflict of laws, etc. ${ }^{93}$ This approach builds the substantive perquisites of refugee status from a vision of international protection which is grounded in a particular vision of the "refugee" and of the needs of refugees. One thinks of citizens of legally-oriented cultures who, when in exile, need reassimilation to a legal fabric to regain their identities. One thinks, in other words, of individuals whose identity is constituted through their legal assimilation to a particular municipal structure of property and status. This first approach to solution is based conceptually, as well as historically, upon the experience of post-war European exiles.

When pursuing the high road to solutions, beyond elaborating refugee status into recognition for international procedural protection, the protection officer typically seeks both to elaborate the boundary between refugee and asylum into substantive rights and to fashion obligations particularly suited to refugees from other duties of international law such as human rights and humanitarian law. ${ }^{94}$ All of these approaches to solution retain an international and legalistic flavor, attempting to posit uniform norms governing treatment of refugees. Being, as they were, reverse engineered from refugee status, all these approaches are directed at ending the conditions for international protection rather than resolving the plight of specific refugees. All exclude direct consideration of the conditions of asylum. From this international perspective, asylum appears as a void. The protection officer is concerned with access to it and departure from it but finds no way to relate directly to asylum as a condition. Indeed, the distinction between international and national becomes, in the asylum context, synonymous with the distinction between jurisdiction and solution.

To the extent refugee-based strategies seem the high road to solution, pursuing an independent international definition for asylum seems either impossible or conceivable only if one can put asylum back on the high road by internationalizing it or if one resigns oneself to the low road of a purely pragmatic, case-by-case approach. Efforts of the first type, which accept the boundary between international law and national discretion, typically either fail or succeed only in relocating national discretion. Attempts of the second

93. See, e.g., Convention, supra note 22; Convention Relating to the Status of Stateless Persons, signed 28 September 1954, entered into force 6 June 1960; 360 U.N.T.S. 130. See generally Weis, "The International Protection of Refugees," 48 Am. J. Int'/ L. 193 (1954); Weis, "Legal Aspects of the Convention of 28 July 1951 Relating to the Status of Refugees," 1953 Brit. Y.B. Int'l L. 478.

94. Thus, for example, we find attempts to transform the recognition of refugee status into an international principle of nonrefoulement, and then into a municipal obligation of admission. See supra section V. See also G. Goodwin-Gill, supra note 2, at 138-140, 148, \& 219ff; Garvey, "Toward a Reformulation of International Refugee Law," 26 Harv. Int'I L. J. 483 (1985); Young, "Between Sovereigns: A Reexamination of the Refugee's Status," 1982 Mich. Y.B. Int'/ L. Stud. 339. 
type seem unable to say anything more than that the asylee gets what states grant. Paradoxically, then, treating asylum systematically as the other of refugee-based approaches to solution has drained asylum of its uniqueness, rendering it dependent upon refugee status for definition, content and usefulness as a workable solution.

To the protection officer who thinks about solutions in this way, the International Law Commission's (I.L.C.) 1950 definition of asylum sounds tautological and unhelpful:

The term "asylum" designates the protection which a state grants on its territory to a person who comes to seek it.95

So long as one thinks of asylum as the low road to solution, this definition will suggest the absence of any substantive content to the idea of asylum and seems to reinforce the sense that international law and national discretion are implacably opposed. It will be interpreted as a sign that asylum belongs to national politics, immune from international law. Although this interpretation fits the protection officer's sense of the U.N.H.C.R.'s jurisdiction, it distorts the notion of asylum, both historically and doctrinally. A reexamination of the doctrinal history of asylum suggests that the 1950 I.L.C. resolution be read as a sign of decentralization rather than of monolithic sovereign discretion.

\section{B. Historical Precedents}

The contingency of contemporary notions about asylum as a solution emerges sharply when contrasted with European notions of asylum before 1700 and during the late nineteenth century era of high positivism. Texts from the early period delimit no coherent doctrinal notion of asylum, let alone one of a particularly national, discretionary or political form. Scholars wrote of various hospitalities and protections accorded by princes or other authorities to one another and to citizens in various situations, but there was no uniformly recognized status by the name "asylum" or any other name whose content could be assessed and whose attributes could be measured. ${ }^{96}$ The protections and hospitalities of which they wrote were thought

95. Resolution on Asylum, A.1, Institute of International Law, Bath Session 1950, 43(1) A.I.D.I. 157, 45 Am. J. Int'I L. (1951, Supp. 15). Compare Coles, "Temporary Refuge and the Large-Scale Influx of Refugees," Aust. Y.B. Int'l L. 190, 200 (defining "asylum" as "the protection accorded a person seeking protection").

96. One might collect bits and pieces of doctrine from various places in the work of Grotius or Gentili which described protections accorded people who might today be regarded as refugees and call this resulting collection the "origins" of modern asylum law, but such a collection would not do justice to these earlier scholars. See section III, supra notes 43-55. Neither Suarez nor Vitoria considered the issue. See Kennedy, supra note 44. 
to be binding, but were neither uniform nor integrated into a single doctrinal category. On the contrary they seemed to be responses to the particular needs of those requesting protection. Doctrinally, these texts speak less of a single status to be granted, which entailed particular rights and duties, than of a variety of protective activities encouraged by considerations of a universal legal and moral fabric for people who, for one or another reason, were "unfortunate." 97 Thus, historically, those who were protected by states had little of importance in common. One found merchants fleeing debts, peasants seeking to escape feudal bonds or replace collapsing allegiances, children of mixed-class parentage seeking license to trade, members of religious orders and their flocks seeking princely support or freedom to practice their faith, and traders seeking military assistance against pirates or in recovery of property at sea. Many of these individuals received the protection they sought merely by being present elsewhere, for example in a different religious area, while others received special assistance.

In this early period, these people were referred to as "exiles" (voluntary and involuntary) and "suppliants," but these were not status categories.98 Exiles were those who had left their home, seeking to resettle elsewhere, as a result of some fear of disaster. The reasons mentioned en passant for their exile included religious persecution, criminal prosecution (just and unjust), war, slavery and general misfortune. It is important to note that these conditions did not trigger a legitimate "exile" status, but merely described some of the reasons people might flee. Princes welcomed exiles, not because their status triggered a duty, but because it was just to do so unless there was some reason rendering it unjust to do so. Since the welcome granted was not triggered by the doctrinal structure of the exile, it was never doctrinally elaborated.

"Suppliants" referred to people requesting that a sovereign right a wrong or protect an interest. A suppliant, for example, might be an exile requesting

97. See, e.g., H. Grotius, supra note 44, Book II, section V, at 550. This was even truer of Asian and African practice. In Asia, with less legal conceptions of borders and nationalities, the variety of treatment accorded migrants, foreign establishment figures, and pirates was broad. See, e.g., Fitzgerald, The Southern Expansion of the Chinese People (1972) (especially at $107 \mathrm{ff}$ ); S. Iwao, Biographical Dictionary of Japanese History (1958) (containing fascinating sketches of individual transfrontier success stories, in particular those of Yamada, Nagamasa, Takayama, Ukon, Wani, Ganjin, and Gembo); Murdoch, "The History of Japan," The Japan Biographical Encyclopedia and Who's Who 306ff (1958). Basic facts about the African experience are to be found in R. Olive, The Cambridge Encyclopedia of Africa (1981). Particularly interesting descriptions of intertribal migrations and protections generated by the dislocation of the slave trade are collected in The African Slave Trade from the Fifteenth to the Nineteenth Century. Reports and papers of the UNESCO meeting of Experts at Port au Prince (1978). In particular the papers of Gerbeau, Kake, and Gueye contain useful bibliographies. See also W. McNeill and R. Adams, supra note 53.

98. See, e.g., Grotius, supra note 97 , at 232, 530-535; Vattel, supra note 47, at $\S \S 228-231$. C. Wolff, The Law of Nations (1764). 
assistance in recovering property. Although the texts reflect a general sense that such requests should be granted unless it is unjust to do so, the crucial point is that these authors were not concerned about ascertaining an obligation but about elaborating the conditions of justice. Thus, the practice of protecting exiles from the claims of their home sovereign is discussed, not as an aspect of asylum but as one of a number of limits upon a sovereign's ability justly to acquire and sustain rights over subjects. ${ }^{99}$ The granting of immunities to suppliants against prosecution is taken up in the elaboration of the justice of sharing punishments among rulers and ruled, that is, as a consequence of guilt, not discretion. ${ }^{100}$

In this early period, to define asylum as the "treatment accorded," in the language of the I.L.C. resolution, would say nothing about whether that treatment was doctrinally obligatory or predictable. The early European tradition differed remarkably from the vision of asylum which we see through the lenses of an internationalized notion of refugee status. Neither defines "asylum" as a condition with specific international legal attributes. For moderns, this seems to be a failure, an absence of legal status, a deficiency in the elaboration of international law. It seems so because, in this modern vision, to be beyond legal status is to be nothing, to be whimsy or politics. In the early vision, however, this lack of a definition was not a deficiency. The need for a legal status simply did not arise in a world which neither placed the sovereign at its center nor distinguished law from politics and morality. Rather, a wider range of people received as a matter of their just due a wide variety of solutions in unfortunate circumstances.

The nineteenth century positivist typically viewed asylum as a sovereign right of states, a vision at odds with both our own and its predecessor. ${ }^{101}$ This notion developed progressively as scholars differentiated international from municipal law and positive law from morality and politics. As earlier, more integrated notions of international society were transformed into legal rights, capacities and statuses, asylum was classified in different ways. In the writings of Wolff, it appeared as a normatively obligatory, if modified, capacity of states. In those of Pufendorf it was viewed as a humanitarian obligation which states remained legally free to disregard. ${ }^{102}$ All these traditional texts reflected the sense that asylum, regardless of its legal status, was normally to be granted.

The development of a unified notion of a unilateral sovereign capacity to grant asylum did not reflect so much a hardening of attitudes about exiles as a reorientation of the vision of sovereignty. Attempts to square the practice of asylum with growing notions of sovereign independence and author-

99. Grotius, supra note 97.

100. Id.

101. See supra notes $36-87$.

102. See Weis, supra note 43, at 175 . See also Wolff, supra note $98, \S \S 145,147,303 \& 1063$. 
ity were directed not to diminishing the force of asylum or the frequency of its being granted, but rather to account for its continued viability in an era in which sovereigns were understood to have complete authority over their nationals. The important part of the nineteenth century sovereign "right to asylum" was not that it was a sovereign rather than an individual right but that it was a right against the home rather than the host state. In other words, this approach was primarily concerned to resolve conflicting assimilation claims by host and home sovereigns and did so in favor of the institution of asylum.

This was done by treating asylum as the result of the priority of territorial jurisdiction over other claims by a sovereign upon his subjects. The "asylum" itself was simply the result of this priority. Oppenheim, beginning his seem= ingly more modern discussion of the "so-called right of asylum," echoes this vision of asylum as the consequence of jurisdictional conflict by saying:

- The fact that every State exercises territorial supremacy over all persons on its territory, whether they are its subjects or aliens, excludes the prosecution of aliens thereon by foreign States. Thus, a foreign State is, provisionally at least, an asylum for every individual who, being prosecuted at home, crossed its frontier. ${ }^{103}$

Yet merely because asylum was doctrinally understood to depend upon national boundaries did not mean that it resulted from them in any historical or substantive sense. This approach to asylum was a way for positivists to account for a pre-existing institution which had its own substantive content within their vision of sovereignty.

Nevertheless, as asylum was assimilated to a system of bounded sovereign authorities, it began to take on a more uniform and limited quality. Gone from view was the variety of protection activities accorded and employed in the pre-1700 period. One now thought only of protection which could be doctrinally derived from sovereign boundaries: primarily protection from capture and prosecution or extradition. In this sense, asylum derived a uniform meaning in response to its assimilation to an image of the sovereignty against which it could be invoked rather than from the diverse needs and protections of exiles. Although this reorientation of asylum, by making it dependent upon a picture of sovereignty, brought it closer to our image of asylum, it should be stressed that this did not yet mean that asylum could be given no international content or have no legal force. Nineteenth century asylum was neither uniformly national nor unpredictable. It remained a condition whose contours could be seen from the international doctrinal boundaries which enabled it. ${ }^{104}$

103. L. Oppenheim, International Law 551 (McNair ed. 4th ed. 1928) (emphasis added).

104. This international condition, it should be noted, had nothing to do with admission of exiles or with nonrefoulement. In these days before the systematic regulation of borders, asylum referred to the protections available for foreigners within a territory, or in certain 
In this, asylum came to be defined in a way which was dependent upon international theories of sovereignty rather than responsive to the needs of refugees. Nevertheless, the positivist vision of asylum was based on an ongoing practice of hospitality and took a uniform shape in response to asylum's internationalization, not to its exclusion from international law. The increasing tendency to consider asylum as something to be granted was associated with a regularization of the conditions under which it would be granted and a clarification of what it consisted of, both of which reflected its position in an international doctrinal structure. ${ }^{105}$

Moreover, unlike both modern and earlier notions of asylum, nineteenth century asylum doctrine was completely unconnected to the notion of "refugee." For earlier scholars, both the situation of the suppliant and his treatment were matters of justice. For the modern, even if asylum and refugee are imagined to be one another's opposite, created and sustained on different levels, it remains true that the one is regarded as the response to the other. In high positivist literature, asylum grew as a protection separate both from uniform notions of its justice or injustice in particular situations and from a particular qualifying status. This independence of asylum in positivist literature poised it to become the discretionary other of a regularized international refugee status, but this later development was in no sense required by the doctrinal notion of asylum as a sovereign right. Thinking of asylum as dependent upon a set of jurisdictional boundaries instead of a set of notions about justice enabled asylum to take many forms, but did not at that time signify anything about a state's ability to refuse to grant asylum or to grant it on any terms. In fact, as to the latter point, the dependency of respect for asylum upon international notions of jurisdiction suggested that the protection granted, to be respected, would have to be of a particular type, rather than of any type.

\section{The Contemporary Approach to Doctrines of Solution}

International lawyers concerned with refugee protection have transformed positivist discretion into license. As their international legal competence to protect refugees has solidified, international lawyers have increasingly come to the view that international consensual law is the only impediment to national whim. As a result, they have overemphasized the political and discretionary nature of asylum. In a self-fulfilling prophecy, these scholars and lawyers have transformed the notion of asylum as a sovereign right from a

cases extraterritorially. See $2 \mathrm{~A}$. Grahl-Madsen, supra note 2, at $17 \mathrm{ff}$; Weis, supra note 43 (describing the relationship between the development of systematic extradition agreements and procedures and asylum doctrine).

105. See R. Plender, supra note 4, at $38 \mathrm{ff}$; see also 1 A. Grahl-Madsen, supra note 2 , at $57 \mathrm{ff}$. 
defense of the institution into a threat to it. By overemphasizing asylum's national character they have underestimated their ability to give it international contours.

Protection officers often defend this approach by characterizing it as an uncompromising dogmatic position, preserving what slim notion of asylum seems to exist after the battering of a hundred years of positivism. In fact, however, they tend to disregard the major source of asylum's international substantive content and to confine their attention to a narrow vision of acceptable protection previously suited to Western, north-north refugee flows. By transforming the idea of a sovereign right into sovereign discretion, they have severed the connection between asylum and solutions which was implicit in its development as an adjunct of sovereign territorial jurisdiction and mutual respect. This approach cost nothing so long as the internationalization of refugee status was able to take up the slack by providing a minimum standard of treatment (international protection, legal reassimilation and nonrefoulement) which was suited to the needs of refugees. So long as most refugees were Europeans, this remained true. It is, however, no longer true that the attributes of an international refugee status, as enumerated in the Convention and Protocol, either apply to large numbers of refugees or are suited to their needs. ${ }^{106}$ Meanwhile, asylum had lost its ability to respond internationally to the needs of diversely situated exiles and unfortunates.

\section{An Alternative Approach to Asylum and Solution}

It has become difficult to imagine an asylum doctrine which is neither a matter of national discretion nor of international right. Of course, it is not possible to return to a pre- 1700 conception of asylum as a disaggregated body of just responses to misfortune. Once the spheres of international and national and of law and morality were separated and the sovereign was placed at the center of our world order, calling asylum "a humanitarian duty of states" weakens rather than strengthens it. It is also not possible to return to a high positivist defense of asylum separated from a notion of an international refugee status which might trigger it. Once the supremacy of sovereigns over individuals has been legalized and transformed into a matter of reciprocal rights, duties and status, calling asylum a "sovereign right" tends to weaken, not strengthen it.

106. It is interesting to note that the essentially European system of refugee protection was extended beyond Europe by the Protocol simply by removing a geographic and temporal restriction on the work of the U.N.H.C.R. and by urging wider ratification of the original convention rather than by designing an approach to extra-European refugee situations particularly suited to their diverse character. See Weis, "The 1967 Protocol," supra note 22 , at 39. 
It seems equally unpromising to seek to legalize or internationalize asylum status in the style of refugee status, because asylum has developed quite apart from refugee status, as an outgrowth of the mutual respect inherent in sovereignty. It also seems unpromising to treat asylum as a national discretion to be tamed by a convention specifying the minimum standards of treatment which asylum implies, because asylum is less a status to be conferred than a protection which results from other actions and which is constituted by the contours of territorial sovereignty. In general, it seems unpromising to treat asylum as an internationally uniform status, for asylum is grounded more in the diverse protection needs of individual asylum seekers than such a uniform approach would suggest. Nevertheless, acknowledging that asylum developed in response to changing visions of sovereignty in international life should permit us to stop overemphasizing its national discretionary, and hence, presumably unknowable quality.

In such an alternative vision, asylum might be seen as an international response to misfortune and dislocation. The language of Article 14 of the Universal Declaration of Human Rights illustrates this alternative approach. Article 14, paragraph (1) provides that: "Everyone has the right to seek and to enjoy in other countries asylum from persecution." 107 Contemporary international lawyers tend to read this article as if the words "if granted" were placed before the words "to enjoy." They read this article as if it confirmed the view that asylum can be withheld for any reason and granted on any terms by states. ${ }^{108}$ If we suspend the sense that the only important question is the legal obligation of the "granting" sovereign and instead view the asylum to be sought and enjoyed as an international institution, we might read Article 14 so as to give asylum international content without interfering with its sovereign roots.

It is not at all clear, for example, that asylum must be granted to be enjoyed. As Oppenheim noted, to be abroad under a system of territorial jurisdiction is to enjoy an asylum. In this sense, Article 14 merely restates the limits on extraterritorial sovereign jurisdiction. This protection need not be granted and may, under normal circumstances, not be withdrawn except in accordance with rules governing expulsion, including nonrefoulement. If the right to seek asylum is to mean more than the right to depart one's country, it must mean that this preliminary protection continues while any procedure for reviewing the permanence of asylum is conducted. One could

107. G.A. Res. 217A, U.N. Doc. A/810 at 74 (1948).

108. This image is buttressed by the fact that the words "to enjoy" were added to the draft by the General Assembly to replace the words "be granted" which had been proposed by the United Nations Human Rights Commission. See Aga Khan, "Asylum - Article 14 of the Universal Declaration of Human Rights," VIII J. of the Int'I Comm. of Jurists 2 (1967); Weis, "The Right to Asylum in the Context of the Protection of Human Rights in Regional and Municipal Law," 1966 Int'I Rev. of the Red Cross 1-8. Cf. Weis, "The United Nations Declaration on Territorial Asylum," 1969 Canadian Y.B. Int'l L. 92. 
characterize this notion of asylum as an obligatory grant of temporary protection, but to do so would return to an emphasis on sovereign discretion and obligation. The point is to elaborate asylum from the international system of jurisdiction which constitutes it. By doing so, the overwhelming modern emphasis upon asylum as discretion will be diminished.

Moreover, it is not at all clear that an asylum granted on any terms would be "enjoyed." Of course, from the individual asylee's point of view, an asylum which did not respond to his needs for protection would not be an asylum. Moreover, from an international perspective, the words "to enjoy" signal the respect which an individual can expect to be shown in his asylum by other states, including his home state: the asylee has a right to enjoy his asylum in one state without interference from other states. This view, of course, is also merely a restatement of the sovereign obligation to respect territorial sovereignty. Yet such respect need not be accorded an asylum on any terms.

An asylum which was not voluntary, for example, need not be respected, for no state can imprison or detain the citizens of another without cause and maintain friendly relations. By voluntary, we must also comprehend reversible, for no sovereign need respect attempts by another forcibly to enslave, conscript or refuse exit to its nationals. To be respected, asylum, as an institution expressing territorial jurisdiction, must be enjoyed in the territory of the host state. Moreover, if we think of asylum as the expression of territorial jurisdiction, it must be conditioned as territorial jurisdiction is itself conditioned, upon respect for fundamental human rights and upon reciprocal respect for sovereign integrity. Thus, if the asylee is permitted to use the host territory for commission of international crimes or violations of another state's territorial jurisdiction, one would cease thinking of an asylum which needed to be respected and could continue to be enjoyed.

If we think of asylum as the safety of integration into a territorial jurisdiction, it may not be too much to think of a substantive integration, for the asylee can be protected from dependence upon his home state only to the extent of his actual assimilation to new jurisdictions. Thus, if he is to be subject to host state jurisdiction, it might seem that the host state must replace such normal functions of the territorial sovereign as registration of births, deaths, marriages, property transactions and so forth. If asylum is the product of territorial jurisdiction, it must take on the attributes of territorial jurisdiction.

It also seems clear that asylum, if it is to be respected as a "not unfriendly" act, must be not only a genuine extension of territorial sovereignty, but a justified one. It would clearly be not only unfriendly but illegal to grant asylum extraterritorially to foreign citizens resident in their home states or to grant asylum to all travellers from a foreign state, particularly if they constituted a significant proportion of a foreign sovereign's subjects or did not desire asylum. Thus, one might infer from the obligation to respect asylum 
granted, the reciprocal duty to grant asylum only in deserving or exceptional cases: to refugees or for political reasons.

In short, by seeing asylum as an institution developed in response to changing notions of sovereignty, it is possible to give asylum an international meaning which reconnects it to the protection required by an asylee and the conditions under which that protection must be respected by other states and will therefore be effective. Such an institution of asylum would permit protection officers to ask when territorial sovereignty deserves respect, when hospitality is just and what solutions are appropriate for the widest variety of refugees. Asylum would permit the protection officer to abandon his customary vision of a world of international obligation and national discretion with its legalistic approach to solutions and to discuss more flexible solutions which might be appropriate but which have not found their way into international elaborations of the entitlements of refugee status. In discussing asylum, the protection officer might think of himself sitting with host governments facing a refugee in need of a solution, not sitting face to face debating the granting of an international legal status.

\section{E. Recent Doctrinal and Institutional Evolution}

Although much of the recent international literature about asylum, particularly literature generated by the 1977 Conference on Territorial Asylum, has tended to focus rather exclusively upon attempts to legalize asylum as refugee status was legalized, there is some indication that an alternative approach has begun to enter protection discourse. ${ }^{109}$ This alternative international approach to asylum renounces the doctrinally and historically mistaken consignment of asylum to a discretionary void from which it needs to be relegislated. It is based upon the notion of an effective protection that is responsive to an asylee's needs and has been gaining ground based in state practice, particularly at the national and regional level, and in recent U.N. discourse.

In a very decentralized way, we can seen in the various notions of "asylum elsewhere" which national immigration authorities use to allocate asylum seekers to countries of "first asylum" some common notions of the asylum which states are willing to respect, at least for purposes of refusing themselves to grant asylum. ${ }^{110}$ These practices indicate that, at a minimum, states respect an asylum which includes both physical security and protec-

109. See Gilbert, supra note 66.

110. Of course, any summary of these diverse practices of respect is bound to be incomplete and misleading, at least insofar as states may expect less elsewhere for these purposes than they might themselves be willing to grant with the exception that their asylum would be respected. See supra notes 36-87. 
tion against non-refoulement. As criteria for recognition of first asylum are harmonized internationally, one might become able to discern a clearer notion of a minimum "genuine link" between the asylee and the country of recognized first asylum that will ground asylum in the particular protection needs of an individual asylum seeker.

Whether cast in terms of "asylum" grants or refugee "protection," regional asylum practice has consistently treated asylum as a status geared to specific situations and constituted to meet the reasonable and predictable protection needs of particular refugees without interfering with home country sovereignty. 111 The Latin American conventions are firm in their orientation, making asylum an expression of sovereign authority shaped by the requirements of mutual respect. By approaching asylum in this way, they have created an institution particularly suited to provide acceptable and durable solutions to the protection needs of asylum seekers. In other areas, asylum is sometimes joined to recognition of refugee status and sometimes independent. In either case, at the regional level, asylum is a flexible institution which responds in different ways to international cultural, ethnic and political solidarities and is always associated with solving the protection difficulties of exiles and refugees.

Focusing upon these elements, rather than searching for doctrinal consistency, would allow protection lawyers to account for differential tendencies to treat protection as a formal or informal, and legal or political privilege or right. These distinctions matter if protection officers regard only a normative legal status as an international asylum. Seeing asylum as an international solution reveals much more diversity in what is regarded as a solution worthy of respect and allows protection officials to focus on whether the particular asylum is in fact suitable for the refugees concerned, accepting that different protection may be desired or acceptable in different situations, without fearing that this acknowledgment will erode some mystical uniform status called the "principle" or "institution" of asylum.

The more objective definition of refugee in regional documents, particularly those of the Organization of African Unity (O.A.U.), suggests a greater willingness to grapple directly with the causes and solutions for particular refugee problems internationally without abandoning political context. ${ }^{112}$ This flexible integration of the legal and the pragmatic is indicated by the post-independence tradition of differential treatment for refugees from liberated and non-liberated areas. If these disparate regional practices are seen through the lens of a European distinction between law and policy,

111. See 1 A. Grahl-Madsen, supra note 2, at 57ff; G. Goodwin-Gill, supra note 2, at $151 \mathrm{ff}$.

112. See, e.g., Report on the Regional Seminar on Protection of Refugees in Latin America (1979, Mexico City, HCR/120/1/80/GE.80-0687); Goundiam, "African Refugee Convention," Migration News 3-8 (March-April 1970); Weis, "The Convention of the OAU Governing the Specific Aspects of Refugee Problems in Africa," 3 Hum. Rts. J. 39 (1967). 
their context specific notions of asylum seem "politicized" and preclusive of any role for the international community. Seeing these approaches as part of a tradition of responding to situations with solutions rather than legal categories suggests a role for the U.N.H.C.R. in assisting governments to ascertain and provide appropriate solutions. In this light, the "best endeavors" clause in the undertaking by O.A.U. members to grant asylum may have more punch than a similar undertaking might in the European context where it would be regarded as the hortatory grant of a license to refuse asylum. ${ }^{113}$

The association of asylum with a more flexible approach to solutions has also been gaining ground in the documents of the General Assembly, the Economic and Social Council and the Executive Committee relating to the work of the U.N.H.C.R. In the early post-war years these organs spoke of "assimilating," "caring for" or "naturalizing" refugees rather than of granting asylum.114 The term "asylum" entered discourse about solutions in an ambiguous fashion. Sometimes asylum seemed to refer to a status of assimilation granted by states which had accepted refugees though the refugees still were in need of assistance. ${ }^{115}$ Sometimes asylum was used more narrowly to describe a condition alternative and perhaps antecedent to "repatriation" or "resettlement." 116 During this period, the term "durable or permanent" solution came to refer to asylum, repatriation or resettlement. This more limited use of asylum as something transitory or incomplete existed in tension with what has been termed "asylum in the sense of a permanent solution." This ambiguity, in turn, seems to have been resolved in favor of a vision of asylum as the appropriate response to a refugee movement by more recent documents which speak of "integration into a country of asylum" or equate asylum with the term "host." 117

Taken together, these developments suggest a terminological adaption. Asylum has come to be used to refer to an international solution which responds appropriately to a refugee situation. This internationalization of the term was obscured somewhat by attempts to congeal its meaning doctrinally: as a "temporary" solution, for example. But asylum need not pay the price of doctrinal constraint to be useful in describing and advocating complete solutions, consistent with the needs of hosts and hosted. This is par-

113. See Weis, supra note 112.

114. See, e.g., ECOSOC 11th Session E/1849/Supp.

115. See, e.g., A/32/45/16 December 1977.

116. See, e.g., G.A. Res. 2594, 24 U.N. GAOR Supp. (No. 30) at 61, U.N. Doc. A/7630 (1969); G.A. Res. 2650, 25 U.N. GAOR Supp. (No. 28) at 74, U.N. Doc. A/8028 (1970); G.A. Res. 2789, 26 U.N. GAOR Supp. (No. 29) at 84, U.N. Doc. A/8429 (1971); G.A. Res. 2956, 27 U.N. GAOR Supp. (No. 30) at 64, U.N. Doc. A/8730 (1972); G.A. Res. 3143,28 U.N. GAOR Supp. (No. 30) at 84, U.N. Doc. A/9030 (1973).

117. See, e.g., A/31/39/31/35/30 November 1976; E/1980/80/Add.1, 24 July 1980. 
ticularly clear in documents which utilize asylum in connection with an international notion of burden sharing or assistance.

\section{F. Conclusions About Solutions}

In discussions of solutions for protected refugees, unlike in discussions of jurisdiction, international lawyers tend to use the concepts of refugee and asylum in ways which are related and overlap. Despite this overlap, however, the concepts remain different. In particular, "being a refugee" is discussed as a legal status entailing perquisites, while "having asylum" is discussed as a political condition which may have national legal consequences. By embracing both asylum and refugee while reinforcing the difference between them, the protection officer limits his ability to pursue solutions for refugees. Protection activity becomes separated from the conditions of solution by a veil of legality and the protection officer is forced to choose between what are imagined to be two distinct paths to solution: the one legal and legitimate, if somewhat constraining; the other political and somewhat suspect, if seemingly more responsive to diverse conditions. This forced choice impoverishes both paths to solution and limits the U.N.H.C.R.'s ability to imagine and pursue solutions which cannot be made to appear international, legal and universal. Partly in consequence, the U.N.H.C.R. has focused on formal reassimilation, a classically Eurocentric notion of solution.

The images of asylum used to sustain this crippling choice do not reflect the historical diversity of the asylum institution which developed as a diverse and broad series of protection practices, unified only in response to changing notions of sovereignty. Nor do they reflect asylum's doctrinal dependence upon international notions of territorial jurisdiction. The conditions of asylum are not purely a matter of national discretion, if by that is meant that they can be altered, granted and withheld on any terms. Asylum is decentralized and diverse, but not capricious. Asylum is as bounded as the territorial jurisdiction that sustains it is bounded.

Continued attempts to view asylum as a legal status with a single doctrinal definition have created a great deal of terminological confusion: is asylum "resettlement" or "final refuge" or "assimilation" or "temporary care"? Asylum is, Oppenheim said, the protection which results from being abroad. In this sense, it is a condition rather than a legal status, with a variety of possible attributes. Sometimes asylum will seem too permanent, durable or legal. At other times it will seem too flexible and politicized. When international lawyers acknowledge that solutions will be based upon cultural, economic, racial and political considerations, from the point of view of both the host state and the refugee, asylum provides a place for discussing these factors. 
Asylum can provide an acceptable discourse for considering the precise protection and hospitality appropriate for different situations. There is plenty of room for research into the specific types of solution which will meet the needs of refugees and states in various circumstances. Within the rhetoric of asylum, such discussion can come out of the national political closet.

There is a discernable trend in recent United Nations documents and scholarly writings towards a more flexible approach to asylum. Like the trend in jurisdiction discourse, this approach offers a partnership between states and international institutions in identifying and providing appropriate protections. One might think, then, of a request for asylum (in the absence of a more specific municipal definition) as a request that the government concerned work in the tradition of territorial sovereignty, with the U.N.H.C.R. acting as the refugee's advocate, to identify and provide appropriate protection. Advocacy of specific asylum terms, in this approach, should be grounded in the particular needs of a given refugee or refugee group rather than in the doctrinal elaboration of some imaginary legal status.

\section{THE MERITS OF INTERNATIONAL PROTECTION}

\section{A. A Discourse Between Jurisdiction and Solutions}

The preceding two sections of this article contrast discourse about the scope of international institutional competence in the refugee field with discourse about solutions to the difficulties encountered by refugees. Each of these discourses concentrates upon a different aspect of both refugee and asylum law. Jurisdictional discourse focuses upon the international definition of the term "refugee" and upon the corresponding absence of an international standard for identifying either a legitimate asylum-seeker or an asylee. Solutions discourse focuses upon the perquisites of refugee status and asylum. Each of these discourses relates asylum to refugee in a distinctive way. Jurisdiction discourse tends to contrast the two sharply, while solutions discourse blends them more easily. These differences are in turn constituted by other, deeper differences, between law and politics, or by approaches which seem either international or national, obligatory or discretionary. In each case, asylum is used as the relatively more discretionary, national and political term.

I suggested that the international legal identity of the U.N.H.C.R. led to a separation of jurisdiction and solution discourse, in which only jurisdiction was understood to be primarily legal and international. This distinction and privileging of jurisdiction discourse accounted for the differing relations between the concepts of asylum and refugee in each field. Jurisdiction discourse sustained its distinctive international legal quality in part by excluding asylum as a threatening matter of national politics. Solutions discourse, by 
contrast, attempted to sustain itself within an international legal institution by reintegrating asylum. Each of these typical discoursive patterns distorted the doctrinal and historical complexity of the concept of asylum and has been eroded as the U.N.H.C.R. has grappled with new approaches to a changing set of refugee problems.

Notwithstanding this distortion, the discourse of jurisdiction and solutions has, by pressing a distinction between two extreme visions of asylum and of its relation to international refugee law, defined the task for the discourse of protection. It must reconnect what has been rent asunder and rebuild a workable middle ground between a legal vision of jurisdiction lacking connection to solution and a pragmatic vision of solution lacking international consistency or normative power. Thus, most of the discourse about asylum, oddly enough, is about neither who gets it nor what they get, but about the doctrinal accommodation of sovereign discretion in its granting with international and individual interests in its content.

So far, however, attempts to mediate between absolute visions of asylum either connected to or separate from refugee law and as a matter of either international or national concern, have generated a set of arguments which doctrinally reproduce the choice between sovereign authority and discretion, international law and national politics. This has led protection lawyers to retreat from consideration of either institutional competence or solution into a series of debates whose resolution seems either impossible to achieve or simply a matter of preference. These classic debates about the "right to asylum," "admission and nonrefoulement" or "temporary refuge" distract protection discourse from creative consideration of issues of competence and solutions in light of changing notions of "asylum" and inhibit response to current refugee protection needs.

From the outside, it seems perplexing that protection officers should concern themselves with debates that are not about who should be protected or how they should be protected; that is, issues other than those of jurisdiction or solution. The fact that an enormous amount of energy is spent discussing the "right to" asylum or the "relationship between nonrefoulement and admission" is difficult to explain. Although this work may fulfill the protection officer's mandate to contribute to the progressive development of refugee law, it is difficult to understand why this subordinate institutional objective should press so persistently upon the more central protection issues of jurisdiction and solution.

Preliminarily, it seems that there is a relationship between the popularity of these debates and the structural differences between normal discourse about issues of jurisdiction and solution. As long as solutions discourse is thought too political to be consistent with the U.N.H.C.R.'s identity and jurisdiction discourse seems too legal or formal to generate either effective discussions about the causes of refugee flows or an accurate account of the U.N.H.C.R.'s diverse capacities, there will be a motive to search for an inter- 
mediate way of discussing these problems which more skillfully blends elements of formalism and pragmatism but which retains the flavor of a legal discussion. In this, these debates seek to achieve what both jurisdiction and solutions discourse sought; to transform issues of causes and consequences into matters cognizable by an international institution with a particular legal identity. As a result, these debates combine the transformation of causes into jurisdictional categories with the transformation of results into solutions statuses, seeking to link jurisdictional categories to solutions statuses in a doctrinal fashion. These debates blend these elements in a particular legalistic way, transforming concerns about political flexibility and predictability, about sovereign cooperation and autonomy, into abstract triggers for duties and rights. As a result, these debates do not provide a useful middle ground between stale discussions of jurisdiction and solution. Rather, they succeed only in distracting attention from these issues and reinforcing a limited image of the institution's legal basis.

The protection lawyer comes to these classic debates having learned the lessons of jurisdiction discourse about the distinctiveness of asylum law and the lessons of solutions discourse about its interdependence with other legal fields. Asylum is presumed to be distinctly national and political. Asylum law is distinguished from other branches of law affecting refugees: humanitarian law, human rights, immigration law, refugee law and the laws of extradition, statelessness and nationality. ${ }^{118}$ Once these differences have been firmly established, these debates deploy various mechanisms to overcome the disjuncture between an international legal protection and a national political asylum.

118. This feature is common to those engaging in all three classic debates considered here. See, e.g., A. Grahl-Madsen, supra note 2; A. Grahl-Madsen, Asylum, supra note 24; C. Goodwin-Gill, supra note 2 (whose table of contents represents this quality in the debates over nonrefoulement and admission most dramatically); Weis, supra note 43; Report of the Seminar on International Protection at Monteaux 21 January 1980 HCR/120/5/80 - 1228; S. Krenz, supra note 38; Ricci, "Asile, Extradition et Terrorisme," 21 AWR Bulletin 4:215 (1983); Weis, "International Protection," supra note 93; Feliciano, International Humanitarian Law and Coerced Movements of Peoples Across State Boundaries (1983); Martin, "Non-Refoulement of Refugees: United States Compliance with International Obligations," 23 Harv. Int'l L. J. 357 (1983); G. Coles, Problems Arising from Large Numbers of Asylum Seekers: A Study of Protection Aspects (1981) (unpublished manuscript). The distinctive divided nature of protection discourse which results from its acceptance of this distinction and its consequent position between but not of either jurisdiction solution can be seen in the following description of protection:

The UNHCR protection function has two basic aspects, namely the legal framework and the institutional arrangements ... legal instruments and institutional arrangements which were basically the instruments of protection would be distinguished from direct or immediate protection itself, because direct protection is essentially a practical, pragmatic activity.

Report on the Regional Seminar of Protection of Refugees in Europe ( 7 November 1 December 1978) HCR/120/33/79 GE.80-0027 at 4. 


\section{B. The Debate About "The Right to Asylum"}

Most contemporary treatments of asylum begin with, and many are devoted exclusively to, consideration of a right to asylum. ${ }^{119}$ Scholars who think that this is an important question for investigation, carefully distinguish the right of asylum (or the "right to grant asylum"), which is acknowledged to be the sine qua non of the institution of asylum, from a right to asylum (or the "right to be granted asylum") which, all acknowledge, is more controversial. These two rights are treated as compatible dimensions of an international law of asylum. Because one is seen to be a right of one sovereign against another sovereign and the other is seen to be an individual's right against a sovereign, they do not seem inconsistent. Moreover, were the legal system "complete," we would have both. The controversy about the right to asylum is, for both supporters and detractors, a "deficiency" in the legal fabric. It appears that a legal regime, properly articulated, could fulfill both the aspiration to protect sovereign autonomy (the right of asylum) and an international scheme of refugee protection (right to asylum). ${ }^{120}$ The two elements which neither jurisdiction nor solutions discourse could reconcile are reconciled here, as long as we accept the distinction between these two rights. Sovereign autonomy vis-à-vis other sovereigns is enshrined in the right of asylum. The needs of refugees are protected by their legalization as a right vis-à-vis the host sovereign.

However, this distinction has not been successfully translated into distinguishable legal categories. Rather, scholars have recognized that an individual's right to be granted asylum can conflict with a sovereign right to grant asylum if that sovereign right is understood to imply not simply the expectation of international recognition of asylums granted, but also unfettered discretion to refuse to grant asylum. ${ }^{121}$ As a result, given the relationship between asylum and national sovereign authority, when these two rights have been seen to conflict, the right of asylum has prevailed. But international law scholars seem uncomfortable with a doctrinal corpus which contains only the right of asylum, understood to be the symbol of absolute discretion. A wholly discretionary right of asylum threatens the international legal character of that right by depriving it of any grounding in mutual sovereign respect. As a result, scholars have continued to discuss the right to asylum, seeking either to rehabilitate it within a regime dominated by the right of

119. See, e.g., A. Grahl-Madsen, supra note 2; G. Goodwin-Gill, supra note 2; Weis, supra note 43; S. Krenz, supra note 38; Weis, "The Right to Asylum," supra note 108, at 1-8; Gilbert, supra note 66; Hyndman, "Asylum and Non-Refoulement-Are These Obligations Owed to Refugees under International Law," 57 Philippine L. J. 43 (1982); Morgenstern, supra note 17; L. Green, supra note 24; M. Garcia-Mora, supra note 24.

120. See, e.g., A. Grahl-Madsen, Asylum, supra note 24 , at $2,11 \mathrm{ff}$.

121. Id. 
asylum or to strengthen it by scholarly advocacy, convention drafting or practice.

The debates about the right to asylum which have ensued are familiar. Most commentators have concluded that there is no right to asylum, although they recognize that there may be other obligations (such as municipal rights, non-extradition, nonrefoulement, humanitarian duties) protecting asylum seekers. ${ }^{122} \mathrm{~A}$ minority of commentators argue that there is now a right to asylum, although they recognize that the right may be a qualified one-progressively developing, subject to exceptions, or not fully enforceable or accepted. ${ }^{123}$ Those of the majority take a harder line with respect to the qualifications acknowledged by the minority, arguing that there can be no right until it has been fully developed and accepted, is associated with a correlative duty, or is enforceable. Those of the minority take a harder line with respect to the exceptions acknowledged by the majority, arguing that international law can be composed of municipal legal principles and that the humanitarian obligations which make up the penumbra of human rights law are developing into valid rights.

The majority tends to confine its image of international law to the world of sovereigns. The majority tends to rely upon traditional positivist notions about the consensual and formal sources of international legal obligations, the distinction between law and morality, and the primacy of sovereign autonomy. The minority supports, both historically and doctrinally, the possibility of international legal rights and duties for individuals. The minority tends to rely upon recently rehabilitated naturalist notions of sovereign cooperation and the interdependence of law and morality and tends to take a more liberal view of soft, informal, non-consensual or instant sources of law. These tendencies are obviously not absolute. There are, for example, those who acknowledge that individuals may have international legal rights or that "soft law" may exist, but argue that the right to asylum does not yet make the grade. ${ }^{124}$

The fascinating aspect of this debate, however, is its inconclusive and parallel structure. Both sides accept the basic division of asylum into a sovereign capacity and an individual benefit. Both accept the basic structure of international legal obligation and treat the existence of an obligation as the sine qua non of protection. Each develops a position qualified by exceptions designed to meet the objections of the other, yet neither can account for the

122. See, e.g., A. Grahl-Madsen, supra note 2, and A. Grahl-Madsen, Asylum, supra note 24 (who moved somewhat from the no right position between 1967 and 1980); G. Goodwin-Gill, supra note 2; S. Krenz, supra note 38; Weis, supra note 43; Nanda, "World Refugee Assistance: The Role of International Law and Institutions," 9 Hofstra L. Rev. 435, 451 (1981); Johnson, "Refugees, Departees and Illegal Migrants," 9 Sydney L. Rev. 140 (1980).

123. See, e.g., M. Garcia-Mora, supra note 24; Gilbert, supra note 66.

124. See, e.g., S. Krenz, supra note 38. 
capacity of its acknowledged exceptions to devour its position when confronted by the challenge of the other. Most importantly, neither alone is able to account for sovereign autonomy and cooperation simultaneously.

Taken together, however, the well-worn debate accomplishes what the independent discourses of jurisdiction and solution were unable to accomplish: finding a place for both sovereign autonomy and sovereign cooperation. So long as the debate continues, there is room for positivists and naturalists. Each is present in each line of commentary, whether as the dominant voice or as the voice of the exception.

It is not surprising that a debate in such equilibrium should seem both frustratingly irresolvable and an unimportant matter of preference. The importance of this debate lies in the agreement by both the majority and minority that a right to asylum would be a desirable addition to international law. Both sides are assessing the progress of international law to capture the institution of asylum, to legalize and internationalize the one place which in both jurisdiction and solutions discourse had been reserved for sovereign discretion. The goal of this project is to overwhelm the boundary between international law and national politics; the debaters merely disagree on the appropriate measure of their success. It is not surprising that their debate has stalled, for these commentators all accept both the distinction between international law and national politics and the characterization of asylum as a matter of sovereign discretion. They cannot overwhelm a distinction which they are not prepared to reject.

As a result, it seems inevitable that the "no right to asylum" school will remain the ascendent one, just as jurisdiction discourse will remain ascendent over solutions discourse. Moreover, so.long as this remains the structure of debate, attempts to storm the high ground of sovereignty by establishing a right to asylum either will fail or will relocate national discretion elsewhere, exactly as the minority school acknowledged the claims of the positivist majority in its exceptions and qualifications of the right it professed to describe. In this light, attempts to create a right which "has no remedy," "lacks enforcement" or "may be a right against the international community as a whole rather than against any particular state" can be seen as continuations of this debate rather than resolutions of it.

Thinking of the debate about a right to asylum as an irresolvable repetition of the conflicts distinguishing solutions and jurisdiction discourse reveals how distracting the debate can be. If the task of protection is to get asylum for people, seeking a "right to asylum" distracts protection lawyers into either wishful thinking or resigned skepticism. Until there is a right nothing can be done and yet no right seems defensible or achievable which does not confront us with a new manifestation of sovereign discretion. Moreover, and most disturbingly, this debate, by accepting and reinforcing the disjuncture between international law and national discretion, prevents the U.N.H.C.R. from capitalizing on the new roles thrust upon it by chang- 
ing conceptions of its mandate for asylum situations and its ability to participate with states in developing flexible solutions for the divergent problems of refugees. To continue this debate places faith in an infinite legal process rather than institutional action.

\section{The Debate about "Nonrefoulement" and "Admission"}

In the battle to overcome the disjuncture between jurisdiction and solution, the "right to asylum" debate, with its emphasis on the international legalization of asylum, is the heavy artillery. The boundary between national discretion and international obligation, however, has been resistant to conquest by force. More successful, if in the final analysis equally distracting, have been more subtle efforts to overcome this disjuncture, repeating it in various doctrinal forms whose conflicts can ostensibly be more easily resolved. One such effort has revolved around the concept of "nonrefoulement," literally the "non-return" of a refugee to the country from which he is in flight. ${ }^{125}$

Like the debate about the right to asylum, discussion of nonrefoulement begins with an assumption about the distinctiveness of asylum and refugee law. In this way, nonrefoulement discussions resemble jurisdiction discourse. The nonrefoulement debate is also similar to the right to asylum debate in that discussion of nonrefoulement seems directed to reconnecting these two realms. In this, the nonrefoulement discussion resembles solutions discourse. The connection which is pursued in nonrefoulement, however, is more subtle than the legal takeover pursued by the right to asylum debate.

Legal scholars discussing nonrefoulement proceed in several stages. The first step is to develop nonrefoulement as an international legal obligation. International lawyers have devoted a great deal of energy to developing and strengthening the principle of "nonrefoulement," not as the source of a right to asylum coterminous with it, nor as the source for asylum's substantive content, but as an independent obligation of refugee law. As a result, the practice of nonrefoulement has, over the last hundred and fifty years, been transformed into the "principle of nonrefoulement," which is seen by scholars as a "fundamental" international legal obligation forming the cornerstone of refugee law. Of course, there are exceptions, and state practice, particularly as to opinio juris, is anything but conclusive. Nevertheless,

125. See, e.g., G. Goowdin-Gill, supra note 2 ("non-refoulement is the foundation-stone of international protection"); "Non-Refoulement," Note Presented to the Sub-Committee of the Whole on International Protection by the U.N.H.C.R. (1977) (HCR/PRO/3); Hyndman, supra note 119; Landwehr, The Principle of Non-Refoulement in Refugee Law (with good bibliography); Martin, "Non-Refoulement of Refugees: United States Compliance with International Obligations," 23 Harv. Int'I L. J. 357 (1983). 
scholars continue to insist that the principle of nonrefoulement has become binding as a matter of both treaty and customary law if not also as a so-called peremptory norm or jus cogens. ${ }^{126}$

The important point is not whether these scholars are correct in their assertions about the status of the nonrefoulement principle, but the strength of their insistence and its consequences for the structure of further debate about nonrefoulement. Whether correct or not, these assertions reflect a strong sense that nonrefoulement, as opposed to other aspects of the treatment of refugees, is to be thought of as an international matter of law. Indeed, it is on the basis of this quality of nonrefoulement, regardless of its particular strength, status or content, that one thinks of refugee law as law at all on the international plane. If one manages to think that the key point about nonrefoulement is its international legal character, one can think of refugee law as a legitimate subspecies of international law even if one eventually concludes that nonrefoulement has not (yet) acquired binding force. Nonrefoulement, like refugee law as a whole, has taken a leap towards international legalization through the process of its transformation into a "principle."

In the process, of course, other aspects of refugee treatment have been left behind or, more accurately, have come to be thought of as matters of national discretion. The various protections beyond non-return which add up to asylum now contrast starkly with the internationalized legal principle of nonrefoulement. Indeed, sometimes scholars develop the international legal nature of the "principle" of nonrefoulement in express contrast to the "institution" of asylum. ${ }^{127}$ This contrast helps preserve the notion that both national discretion and international cooperation can be preserved in the system of refugee protection as a whole. States will be required to do something - not return refugees - as a matter of international law, but their sovereign discretion to refuse asylum will not be disturbed.

The nonrefoulement discussion does not rest once states are thought to be under an international legal obligation not to return refugees. The next step is to formalize as doctrinal alternatives the various treatments which might form part of a refugee's reception in a national culture and then to connect these formalizations to nonrefoulement by a process of definition, analogy, deduction or normative implication. Thus, people who discuss nonrefoulement contrast it with other categorical responses to refugees. This process has generated a large number of such "treatments," the most important of which are: recognition as a refugee, nonrefoulement, admission, and asylum.

Being recognized or certified a refugee seems most often a matter of international law - even a specialty of the U.N.H.C.R. protection division -

126. See Hyndman, supra note 119.

127. Id. 
although it is often done by national authorities. Once a refugee, one might be treated to an ever escalating assimilation process which might reasonably be expected to proceed through nonrefoulement to admission and, perhaps eventually, asylum "in the sense of a permanent solution." Typical discussion of nonrefoulement begins by asserting the international legal obligation of states not to return certified refugees. This obligation is then used to imply some set of treatments - such as admission, perhaps on a temporary basis, or permission to apply for asylum, etc.

Lined up in this order, these four terms are reminiscent of the temporal movement of refugees from jurisdiction through international protection to solution. Like that movement, however, this temporal progression is not smooth. There is a disjuncture between nonrefoulement and admission which is like the disjuncture between jurisdiction and solution. The first two terms in this series are conceived as matters of international law, the last two as matters of national discretion. Thus, we again find the disjuncture between two levels of analysis as well as between two moments in a refugee's journey from home to host country. Discussions which seek to link the nonrefoulement obligation to admission are thus directed to overcoming the same disjuncture which bedeviled the discussion about the right to asylum.

But here, the disjuncture is spread out somewhat and does not seem as stark as the disjuncture between jurisdiction and solution or between the right to and the right of asylum. Recognition as a refugee seems the core international institutional jurisdiction. Nonrefoulement, while a matter of international law, is an obligation of states. Unlike asylum, however, nonrefoulement does not seem like a status to be granted, and can therefore be practiced by states without interfering with national political discretion to grant asylum. Similarly, while asylum seems both national and discretionary, the term "admission" seems to imply a formal process of legal entry which, although firmly within the national sphere, might be conducted in accordance with legal norms. Thus, nonrefoulement and admission reach out to one another. Nonrefoulement reaches out from the camp of international legal competence, admission from the camp of national discretion. If only nonrefoulement and admission could be joined, the refugee would slide smoothly from the international protection of refugee status to the national protection of asylum.

The two central terms could be joined if they were seen as corollary international legal obligations: if nonrefoulement implied admission. But this connection would threaten the fragile link between admission and asylum. Nonrefoulement and admission could also be joined if both were viewed as matters of national legal practice. But to do so would threaten the connection between nonrefoulement and refugee status. Either of these strategies of connection, legalization or decentralization, would be like the right to asylum debate in that they would overcome the disjuncture between national discretion and international law by transforming one into the other. 
Like the right to asylum debate, these approaches would relocate the lost term elsewhere, failing to smooth the passage from one sphere to another.

The debate over nonrefoulement, however, is far more sophisticated. The initial separation of refugee status and nonrefoulement split the sphere of international legal obligation from the competence of international institutions. The separation of admission from asylum split the legal treatment of asylum-seekers from the ultimate sphere of national discretion. This division made it easier to imagine admission as the logical complement of nonrefoulement because it could be legalized and yet remain within the national sphere. Such a link, achieved by dividing asylum and refugee status into stages which could be connected, is far more stable than merely suggesting that nonrefoulement, an international legal obligation, should "guide" admission, which remains a matter of national discretion. Once this doctrinal link has been established, nonrefoulement seems the consistent legal face of asylum, and asylum the variable national face of nonrefoulement. The two institutions, which seemed to inhabit different levels and to be understood as one another's other, have been made to seem compatible by the link between admission and nonrefoulement, and yet neither international law nor national discretion has been eliminated from the scene.

Nevertheless, this link is also unstable. The doctrinal link between nonrefoulement and admission threatens the vision of a differentiated refugee and asylum which the debate inherited from solutions and jurisdiction discourse. Consequently, this debate proceeds by repeatedly splitting terms on either side of the disjuncture, in a search for a more stable link.

Sometimes this occurs by introducing a new term between admission and nonrefoulement, such as "non-expulsion." 128 This approach makes it seem easier to retain the association between admission and asylum as matters of national discretion and is a standard of national treatment more easily linked to nonrefoulement. Thus, scholars who investigate the meaning of the principle of nonrefoulement distinguish between "expulsion" and "nonadmittance," or further, between "administrative" and "legal" expulsion or expulsion of the "legally" and the "illegally present." 129 These distinctions constantly recreate the basic disjuncture between the international legal obligation and the sphere of national discretion. If refoulement is thought to mean extrajudicial expulsion, a state is legally obliged to pursue deportation procedures for refugees in their territory but retains the authority both of non-admission and of setting substantive terms for expulsion. Similarly, scholars split the term "admission," rehabilitating a disjuncture between, for example, "mere presence" and "legal admission" to regain a sphere for na-

128. See G. Goodwin-Gill, supra note 2 (considering these various middle positions extensively at Chapter IV).

129. See, e.g., G. Goodwin-Gill, supra note 2, at Chapter IV; S. Krenz, supra note 38. 
tional discretion once control over admission has been lost either legally to the international normative sphere of nonrefoulement or as a matter of fact. ${ }^{130}$

If this debate were to stop at any point, the disjuncture would reappear. By continuing to split the difference and shift among such an array of similar terms one creates the illusion of a coherent legal fabric linking refugees to asylum however difficult it may be to pin down. The problem with continuing this debate, however, is that it distracts attention from both the causes of refugee flows and the terms of their solution. One focuses instead on an ever finer set of distinctions among terms which share something doctrinally with these two issues but do not address these issues. A discussion about the relationship between non-expulsion and non-admission is, in a way, a discussion about the balance of power between the international protection of refugees and the terms of their treatment by national authorities. But it is only in an oblique, associative way that this debate grapples with refugees or asylum. It is more accurate to say that it is at best a substitute for a more direct approach.

This debate is also fueled by a search for doctrinal precision and consistency, with choosing between "non-expulsion" and "admission" as the corollary of nonrefoulement, for example, rather than protecting refugees or assessing solutions. This is the cost of a doctrinal approach. First, one is drawn away from the substantive problems of jurisdiction and solution into an ever finer set of distinctions and, second, assessment of the distinctions of choice among their terms comes to be made out of fealty to the coherence of the doctrinal structure rather than out of concern for refugees or asylum conditions. Discussing the meaning of nonrefoulement or the implications of admission feels like getting to the bottom of the problem of asylum. On the contrary, however, it avoids confronting asylum, preferring instead to imagine asylum as the constantly receding repository of an untouchable national sovereignty.

On the one hand, this debate remains important. In given contexts, so long as people continue to imagine refugee protection in these terms, getting acceptance for one or another doctrinal correlative for nonrefoulement will be important. On the other hand, it is certainly true that neither logically, nor as a matter of practice, are any of these doctrinal connections particularly compelling. The only compelling aspect of the debate is its inability to achieve closure and its grounding in a fundamental disjuncture between international and national competences which cannot be overcome by an imaginative but doctrinal craft. The attempt to produce a single international doctrinal resolution seems even more unlikely to succeed. As a result, this

130. See, e.g., Evans, "Observations on the Practice of Territorial Asylum in the United States," $56 \mathrm{Am}$. J. Int'l L. 148 (1962); G. Coles, supra note 118, at 21. 
debate, while central to much literature about asylum and refugee protection seems, finally, not to matter very much and, like the debate about a right to asylum, to be a matter of preference. It is not surprising, then, that the term of the debate remain murky, for not only does its resolution remain forever out of reach, there is no great incentive to clarify, for to do so would be to abandon the enterprise of doctrinal mediation altogether.

\section{The Debate About "Temporary Refuge"}

If the refoulement debate suffers from a tendency to drift into doctrinal distinctions removed from the sources and solutions to refugee problems, the third major debate within protection discourse about asylum is selfconscious about its return to realism. As such, it typifies a third type of response to the disjuncture between refugee law and asylum. The debate about what has been termed "temporary refuge" frankly acknowledges what it sees as an inevitable disjuncture between the international legal exhortations of international institutions and the practice of national politics. ${ }^{131}$ Refugees are one and asylum is the other.

To those who engage in this debate, the better part of valor is to confront this stubborn fact directly. Any attempt to bridge the gap seems calculated either to drift into wishful speculation or to threaten what these scholars think of as the legitimately exclusive domains of international law and national discretion. Thus, people who engage in this debate typically criticize attempts to link nonrefoulement and admission either for "diluting" the purity of nonrefoulement or for ignoring the inevitably absolute national discretion associated with asylum. The key to this third approach is to turn the vice of this inevitable disjuncture into a virtue. This is done by developing a middle term between nonrefoulement and admission which selfconsciously distances them from one another.

This third approach encourages the international community to provide "temporary refuge" for refugees. By this international lawyers mean to suggest that states confronted with arriving refugees should allow them refuge until alternative arrangements can be made for their ultimate protection. "Refuge" is deliberately left vague, and is certainly not thought of as an internationally uniform legal status. The suggestion that refuge be "provided" is also typically left ambiguous, implying neither an international legal obligation nor a national political discretion. As a result, this approach represents

131. See, e.g., G. Coles, supra note 118; G. Coles, The Problem of Mass Expulsion (1983); Martin, supra note 14; Coles, supra note 95; Gilbert, supra note 66; G. Goodwin-Gill, supra note 2 , at $114 \mathrm{ff}$. 
an institutional adaption to a more fluid protection environment than either of the distinctively normative protection debates.

Those who advocate "temporary refuge" appear to have given up the attempt to develop a normative link between international competence and national politics. Consequently, this approach leaves the disjuncture between nonrefoulement and admission intact. Nonrefoulement remains an international legal obligation compelling provision of refuge. The temporary nature of this refuge ensures that admission remains a matter of national discretion. Rather than interpreting nonrefoulement broadly, to reach out towards solution, this approach interprets it narrowly, to imply only that the cause of the refugee flow be acknowledged and provision be made for some international response. Similarly, this approach interprets admission and asylum narrowly, as matters of national political will disconnected from mere presence. Temporary refuge is thus neither asylum nor nonrefoulement. It is a middle position disjointed from both international law and national discretion.

The trouble is that this middle position is a hybrid of the two poles against which it distinguishes itself. Thus, to distinguish itself from asylum, and reassure us that its provision would not disturb national discretion, temporary refuge is treated as a temporary national obligation which implies some more permanent international response to the refugee's difficulties. Compliance with the international obligation is made to seem as costless as possible-eventually the international agency promises to support or relocate refugees given temporary refuge. Likewise, in contrast to refugee status or nonrefoulement, temporary refuge is treated as a matter of national decision to be achieved by negotiation between the international agency and the national authority. It cannot be granted or certified by the U.N.H.C.R. alone.

The defenders of temporary refuge rightly tout this hybrid quality for linking international solidarity with national solutions. It is even possible, in a variation of this approach, to view temporary refuge as the combination of nonrefoulement and admission, differentiated from refugee status and asylum. Whether seen as a way of avoiding the difficulties of the nonrefoulement/admission debate, or as a way of finally combining the two terms, temporary refuge offers the protection officer a way of responding to contemporary refugee problems without abandoning his institutional identity or sense of the international law doctrine of refugee and asylum law.

But although the distinctive nature of temporary refuge seems at first to protect the purity of both nonrefoulement (as a binding international norm) and asylum (as a sovereign discretion) this hybrid quality also raises difficulties. Perhaps it is understandable that advocates of temporary refuge have remained somewhat vague about its status, writing sometimes as if provision of temporary refuge were the essence of some legal obligation (like nonrefoulement) and at others as if it were pragmatic good sense when 
political conditions made fulfillment of more stringent international legal duties unworkable. But precisely because temporary refuge combines obligation and pragmàtism, thereby protecting both nonrefoulement and asylum, it also threatens what have become the symbols of international cooperation and sovereign autonomy.

Thus, opponents of temporary refuge have argued that if it is to be pragmatic or grounded in the host state's peculiar capacity to comply, it threatens the absolute obligation of nonrefoulement. Similarly, it has been argued that if temporary refuge is binding (perhaps as nonrefoulement through time), it threatens the discretionary character of asylum and admission, especially if the link to international burden sharing cannot be established with equal normative and practical force. These criticisms rely, as did the defenses of temporary refuge, alternatively upon its claim to be different from both refugee law and asylum. As such, the debate about the validity of a notion of temporary refuge repeats the debate which seemed interminable in the context of a right to asylum and nonrefoulement.

Various responses, both doctrinal and practical, have been developed by advocates of temporary refuge to overcome this conceptual difficulty. Sometimes they suggest that temporary refuge need not mean assimilation nor respond to the full scope of a refugee's needs, as would asylum, or that it is a binding obligation only in cases of mass influx where there might, for other reasons, be no alternative but to comply. These resolutions, however, conspire to create a status for refugees which responds to an international conceptual problem rather than to the needs of refugees or governments. In the extreme, temporary refuge might seem to be better made as unpleasant as possible to protect the doctrinal link to international burden sharing. The temporary refuge debate, although billed as bringing a new realism to discourse about refugees, in fact results in refugee conditions responding to the conceptual disjuncture of refugees and asylum rather than in conceptual responses to the needs of refugees. The limbo which this new "realism" creates for refugees may be necessary to protect the image which international lawyers share of a national discretionary asylum and their vision of exclusive international legal and institutional competence to deal with refugees, but it is not necessary to respond to the needs of host sovereign and refugees.

\section{E. Conclusions About the Discourse of Protection}

Each of these debates represents a creative response to a difficult conceptual problem. They are important debates, and their short-term resolution, however unstable, affects the protection available to refugees in particular situations. Unfortunately, these debates perpetuate what is most damaging about the conceptual vision which generated them: the disjuncture between international legal competence and asylum. All search, moreover, for a doc- 
trinal solution to this disjuncture which, in its generality, could be universal. This reflects the U.N.H.C.R.'s sense of its own role as an international legal institution. Only the cognitive control which such a universalizing resolution permits seems able to sustain the U.N.H.C.R.'s involvement so long as this basic disjuncture is accepted.

The trends towards a more flexible approach to asylum present in contemporary discourse of jurisdiction and solution could be mutually reinforcing, together eroding the distinctions between the domains of jurisdiction and solution as well as between the legal and political activities of protection staff. It has not worked out this way. Instead, the two trends towards a looser notion of the U.N.H.C.R.'s jurisdiction and a broader approach to solutions are often seen to be mutually threatening, thereby reinforcing the difference between jurisdiction and solutions work. ${ }^{332}$

As a result of the unwillingness to abandon a rigid doctrinal distinction between refugee and asylum and a rigid institutional distinction between international and municipal responses to refugee issues, protection discourse has not seized the opportunity to unite its treatment of asylum as a source of jurisdiction and solution. Instead, protection discourse accepts the disjunctures between asylum and refugee, solution and jurisdiction, political and legal, national and international, and goes on to pursue debates bent on reconnecting through normative discourse what it has differentiated conceptually. The resulting debates, of which the discussion of the right to asylum, nonrefoulement and temporary refuge are classic instances, are successful in their integration project only because they are interminable, continually deferring the moment of connection. No single position within any of these three debates satisfactorily permits a sustainable international normative involvement in national discretion.

In the meantime, these debates distract institutional attention from both causes (legally transformed into jurisdiction) and solutions, substituting a rhetoric of universalistic legal labels, competing with one another in an imaginary doctrinal world in which imputed interests and legal status take on the quality of real things to be balanced and resolved. The danger of continuing this distracting practice is that it makes doctrinal differences seem to be real differences, splitting protection work into specialized categories which

132. This vision has also eroded the distinctions between the legal and political activities of the protection staff. Thus, for example, a protection officer whose solutions work seems to have to involve primarily political dealmaking over solutions wants legal clarification of who is and who is not a refugee so that at least the mandate will provide the legal formality and legitimacy which he feels his other activities lack. By contrast, the protection officer whose solutions work with asylum occurs in a very formal and legalized culture, perhaps connected to the legal definition of a refugee, desires that jurisdictional discourse be expanded to absorb the pragmatic considerations which his solutions context cannot provide. 
are the result of conceptual distinctions rather than the divergent functional requirements of refugee situations. Moreover, once specialized, the debate between pragmatists and formalists can be continued indefinitely without becoming a difference about refugee treatment at all.

There is an alternative suggested by contemporary asylum discourse. Asylum offers the opportunity to establish a partnership with states in developing context specific solutions to refugee flows which take account of their causes, as well as the interests and needs of refugees and receiving populations. Seizing this opportunity will mean relinquishing the tendency to distinguish and prefer universal doctrinal approaches to refugee problems. Asylum, as a matter of U.N.H.C.R. competence, would be decentralized, differentially responsive to relatively legalized and nonlegalized cultures and refugees without fearing that one threatens the other. It would blend pragmatic and legal considerations relating to individuals and groups to assist states in providing an appropriate response to refugee flows.

By refusing the development of congealed doctrinal categories, protection officers would refuse the clandestine nature of their nonlegal work. Each point along the refugees' temporal route from flight to solution would be seen to involve international and national, legal and political concerns, and to be of legitimate interest both to states and to the international community. Asylum, in this vision, would be redeemed as it historically was: a process for relating divergent jurisdictions. The U.N.H.C.R., in developing and deploying its expertise, would seek coordination and harmonization of national asylum practices, rather than normative unification and licensed difference. In short, asylum presents the opportunity not for a clarified orthodoxy, but for an invigorating heterodoxy. 